Parlak Kalkan, G. (2021). İstiklal Marşı́nın anlaşılma düzeyinin tespitine yönelik betimsel bir çalışma (Lise ve üniversite öğrencileri örneği). Ana Dili Ĕgitimi Dergisi, 9(4), 1102-1127.

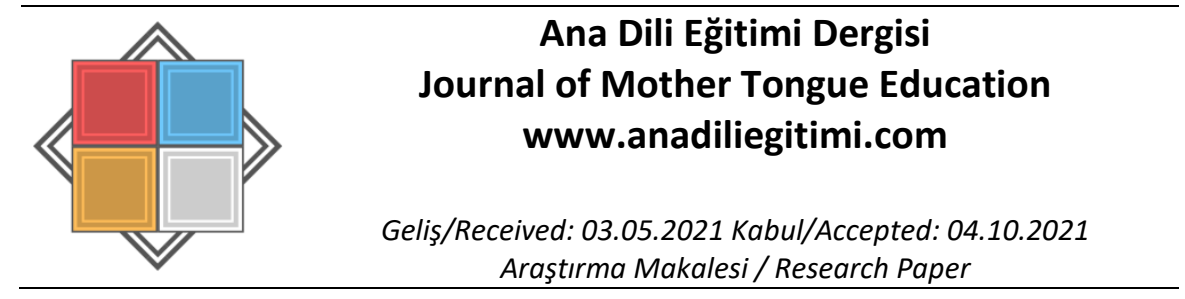

\title{
İstiklal Marşı'nın Anlaşılma Düzeyinin Tespitine Yönelik Betimsel Bir Çalışma (Lise ve Üniversite Öğrencileri Örneği) ${ }^{*}$
}

\author{
Gülşah PARLAK KALKAN**
}

\begin{abstract}
Öz
Bu çalışmada Mehmet Akif'in Türk milletinin tarihine yön veren bağımsızlık mücadelesi neticesinde kaleme aldığı ve edebî unsurlardan ziyade millî bir değer olan İstiklal Marşı́ndaki bazı anahtar kelimelerin lise son sınıf ve üniversite son sınıf öğrencileri tarafından bilinme durumları değerlendirilmiştir. Çalışma için 22 anahtar kelimenin yer aldığı görüşme formu kullanılmıştır. Hazırlanan form (İstiklal Marşı'nın yer aldığı bir nüsha ile), Kilis ilindeki devlet liselerinde son sınıfta öğrenim gören 111 öğrenci ve Kilis 7 Aralık Üniversitesi'nde değişik bölümlerde okuyan 111 öğrenci olmak üzere toplamda 222 öğrenciye uygulanmıştır. Çalışmada ulaşılan bulgular; öğrencilerin İstiklal Marşı'ndaki anahtar kelimeleri bilme/bilmeme düzeylerinin cinsiyete, bölüme ve eğitim kademelerine göre istatistiksel açıdan bazı farklılıklar gösterdiğini ortaya koymuştur.
\end{abstract}

Anahtar Kelimeler: Mehmet Akif Ersoy, İstiklal Marşı, millî değer, lise, üniversite

\section{A Descriptive Study for Understanding to What Degree the Turkish National Anthem is Recognised (Sample of High School and College Students)}

\begin{abstract}
In this study, the knowledge level of final year high school students and final year undergraduate students in some key words of the Turkish National Anthem written by Mehmet Akif in consequence of Turkish war of independence which shapes the history of Turkish nation is evaluated. The Turkish National Anthem is regarded as a national value rather than a literary work. In the present study, an interview form comprising of 22 key words was used. The prepared form (with a copy of the National Anthem) was applied to a total of 222 students consisting of 111 students in state schools in Kilis and 111 students in different departments in Kilis 7 Aralık University. According to the results obtained in the study, knowledge levels of the students about the key words in the National Anthem statistically vary with respect to gender, department and stage of education.
\end{abstract}

Keywords: Mehmet Akif Ersoy, the National Anthem, national value, high school, university

\section{Mehmet Akif ve İstiklal Marşı}

\section{Giriş}

Insan topluluklarının millet olma serüveninde en önemli unsur ortak anlaşma aracı olan dildir. Aynı dili konuşan insan yığınları yine bu dil sayesinde oluşturdukları maddi, manevi değerlerin bütünü olan kültür ile tarih sahnesinde varlıklarını koruyup geliştirerek güçlü ve köklü medeniyetler kurarlar. Dolayısıyla devletleri yaratanın millet bilincine ulaşmış insan toplulukları olması gibi bu toplulukları millet yapan ise dil ve dil üzerine temellendirilmiş din, örf, âdet, merasim, kanun vb. etkenlerin bütünü olan kültürdür (Kaplan, 2010).

\footnotetext{
* Bu çalışma, 12 Mart 2021 tarihinde Şanlıurfa'da düzenlenen “Kabulünün 100. Yılında İstiklal Marşı ve Millî Şairimiz Mehmet Akif Ersoy Uluslararası Sempozyumu"nda sunulan bildirinin genişletilmiş hâlidir.

** Dr. Öğr. Üyesi, Kilis 7 Aralık Üniversitesi, Muallim Rıfat Eğitim Fakültesi, Türkçe ve Sosyal Bilimler Eğitimi Bölümü, Kilis, gulsahparlak@kilis.edu.tr, ORCID: orcid.org/0000-0003-0986-9768
} 
Yakın dönem Türk tarihindeki siyasî, sosyal, iktisadî hayat ile ilgili önemli pek çok bilgiyi eserleri aracılığıyla aktaran Mehmet Akif Ersoy, Türk milletinin Batı tarafından türlü türlü zulüm ve işkencelere maruz kaldığı bir dönemde yaşamış; özellikle Balkanlarda yaşayan Türkleri ve Müslümanları buradan uzaklaştırmak isteyen Bulgar, Yunan ve Sırp çetelerinin yapmış olduğu akla gelmeyecek çirkinlikler karşısında derin üzüntüler yaşamış ve yedi yüzyıllık büyük bir medeniyetin kurucusu olan Osmanlı İmparatorluğu'nun XX. yüzyılın ilk çeyreğinde adeta yok oluşunu izlemek mecburiyetinde kalmıştır.

Balkan felâketinin ardından Osmanlı İmparatorluğu'nu yok oluş sürecine sokacak olan I. Dünya Savaşı başlamış; Türk topraklarının her karışının düşmanlar tarafından işgal edildiği Çanakkale Savaşları esnasında Akif, "Bütün dünya toplanıp hücum etse yine Çanakkale sükût etmez, düşmez!" diyerek kurtuluşa, bağımsızlığa olan inancını zaman zaman kitlelere önderlik eden bir hatip, zaman zaman da eserlerini toplumun hizmetine sunmuş bir sanatçı olarak dile getirmiştir (Karabulut, 2014:2).

Türk milletinin canı pahasına bă̆ımsızlık mücadelesi verdiği bu günlerde Akif tarafından yazılan İstiklal Marşı, yakın tarihe ışık tutması ve edebî değeri yüksek bir metin oluşuyla iki ayrı önem arz etmektedir. İstiklal Marşı, Türk milletinin Batı'nın pençesinde acılarla ve yokluklarla sınandığı, girilen pek çok savaştan ağır yenilgilerle çıkılmasına rağmen vatanın her karış toprağı için canını hiçe sayarak mücadele ettiği günlerde yazılmış edebî bir manzum ya da marş olmanın ötesinde Çetişli'nin (2004:156) de belirttiği üzere "millî mücadele yıllarının en zor günlerinde, ordumuz ve milletimizin en ihtiyaç duyduğu kendine güven, millî heyecan, şevk ve imanın manzum dili" olmak üzere doğmuştur. Nitekim eserin yazılışı öncesinde ve sonrasında zuhur eden durumlar da bu görüşleri destekler niteliktedir:

Millî mücadelenin devam ettiği 1920 yılı sonlarında Garp (Batı) Cephesi Kurmay Başkanı İsmet Paşa, Maarif Vekili Dr. Rıza Nur'a Fransızları örnek göstererek askerlerin millî duygularını harekete geçirip onları coşturacak bir marşın yazılmasının gerekliliğinden bahseder. Bunun üzerine Dr. Rıza Nur Bey, İsmet Paşa'yı Orta Öğretim Müdürü Kazım Nami'ye yönlendirir. 25 Ekim 1910'de Hâkimiyeti Millîye gazetesinde Maarif Vekâletince İstiklal Marşı yarışması düzenleneceği ve yarışmayı kazanana 500 lira verileceği duyurulur. Bu kadar millî bir meselede para mevzu bahis olunca Akif, yarışmaya katılmak istemez (Kaymaz, 2009:39). Bu süreçte yarışmaya toplam 724 başvuru olur. Ancak Akif'ten herhangi bir girişim olmayınca meselenin verilecek ödül olduğu anlaşılır. Rıza Nur'un Moskova'ya görevlendirilmesi nedeniyle yerine getirilen Hamdullah Suphi, Akif'e bir mektup yazarak yarışmaya mutlaka katılmasını, ödül mevzusunun ise bir şekilde halledilebileceğini ifade eder. Mehmet Akif'in konuyla ilgili en büyük endişesi ortadan kalkınca Mehmet Akif, fikren ve ruhen kendini hazır hisseder ve takip eden 48 saatlik bir sürede gece gündüz, uyumadan, yemeden içmeden yazdığı şiiri 7 Şubat günü Millî Eğitim Bakanlığı'na teslim eder (Gündüzalp, 2008:220-221). Neticede 725 şiir arasından Akif'in şiirinin de yer aldığı üç şiir, Genelkurmay'a gönderilir ve ordu tarafından Akif'in şiiri beğenilir (Kocakaplan, 2015:19). Aynı zamanda Hamdullah Suphi, 12 Mart 1921 tarihli meclis görüşmesinde, Akif'in şiirini okur ve şiir milletvekilleri tarafından çok beğenilir; Atatürk başkanlığındaki mecliste Akif'in şiiri büyük bir oy çokluğu ile Türk İstiklal Marşı olarak kabul edilir (Çetin, 2014:35). Yarışmaya konulan ödül ise Ankara'nın ayazında meclise paltosuz, ince bir ceketle gidip gelen Akif tarafından fakir kadınlar ve çocuklar için kurulan Darülmesai'ye bağışlanır (İşcan ve Şimşek, 2012:349).

Atatürk'ün "Hakkıdır, hür yaşamış bayrağımın hürriyet / Hakkıdır; Hakk'a tapan milletimin istiklal." dizelerindeki hürriyet ve istiklal sevdasının Türk milleti tarafından asla unutulmamasını, her dönemde bu dizelerin aynı heyecanla tekrar edilmesini istediği İstiklal Marşı, bir süre Türkiye'nin değişik bölgelerinde farklı şekillerdeki bestelerle çalınmış; 1930 yılında ise Cumhurbaşkanlığı Orkestrası Şefi Zeki Üngör'ün bestesi millî marş olarak kabul edilmiştir (Çetin, 2014:36).

İstiklal Marşı, marşın ötesinde millî duyuş-düşünüşün, millî acıların, millî direnişin tezahürü niteliğinde bir eser, dâhil olduğu kültür çevresinin dışına taşmayan, milletin bir dönem yaşadığı zulme karşı canı pahasına, açlıkla, yoklukla verdiği mücadelenin şiirselleşmiş somut delilidir. Mehmet Akif'in başta İstiklal Marşı olmak üzere millî değerler açısından değeri yüksek tüm eserlerini doğru okuyup anlamlandırabilmek için onun gücünün gerçek kaynağı olan şahsiyetini de tanımak elzemdir.

\section{Mehmet Akif Ersoy'un Şahsiyeti ve Fikir Dünyası}

İstiklal Marşı'nı doğru çözümleyip özümseyebilmek için marşın mutlak suretle Mehmet Akif'in şahsiyetinde taşıdığı meziyetlerle birlikte değerlendirilmesi önem taşımaktadır. 
Her toplumun tarihinde, ömrünü toplumun aydınlanmasına vakfeden ve özellikle buhranlı zamanlarda sıkıntılarla mücadele için en ön safta bulunup gerekirse hayatını dahi seve seve bu uğurda gözden çıkaran aydınlar, sanatkârlar, düşünürler vardır. Gerek düşünce felsefesi gerekse toplumcu sanat anlayışıyla yakın dönem Türk edebiyatı ve tarihinin en önemli isimlerinden biri olan Mehmet Akif Ersoy, salt bir şair değil, Türk milletinin bağımsızlık mücadelesi verdiği Kurtuluş Savaşı yıllarında gücünü ve ilhamını yerli unsurlardan alan büyük bir şahsiyettir.

"Haksızlık karşısında susan dilsiz şeytandır." inancıyla yaşayan Akif, gördüğü her türlü haksızlığa karşı duran samimi bir Müslüman, milleti gibi düşünen, duygulanan, heyecanlanan bir Türk olmasının yanında onun büyüklüğünün ispatı olan pek çok şey mevcuttur: Baytar Mektebi'ni birincilikle bitirmiş, Türkiye Büyük Millet Meclisi'nde mebusluk yapmış; hayattaki en mukaddes iki şeyden birinin din, diğerinin ise dil olduğuna inanmış ve Türkçeyi eserlerinde adeta kuyumcu titizliğiyle işlemiştir. Ayrıca Türk ordusunun iki yüz elli bin şehit verdiği Çanakkale Savaşları'nı adeta destanlaştırdığı Çanakkale Şehitlerine şiiri ile esareti lime lime olmak pahasına kabul etmeyip bağımsızlık için haykıran bir milletin ruhunu işlediği İstiklal Marşı'nı yazmıştır. Öte yandan Dârülfünun'da edebiyat hocalığı, Mısır'da müderrislik yapmıştır. Ancak onu asıl büyük yapan, fikir dünyasıdır (Sarı, 2003:167-168).

Akif, sanatı ve eserleri yanında yaşam düsturu, karakteri ve düşünce ile eylemin paralelliği bakımından da önemli bir şahsiyettir. Ömrünü dinî, millî ve vatanla ilgili mevzulara kafa yormakla geçiren şair, II. Meşrutiyet'ten Cumhuriyet'e uzanan dönemde Batılı emperyalist devletlerin kanlı saldırılarda bulunduğu bir zaman diliminde inandığı doğrulardan asla vazgeçmemiş, pes etmemiş; gerek şahsiyeti gerekse kaleme aldığı eserleriyle topluma hizmet etme gayesinde gücünü din, vatan, millet, bağımsızlık gibi değerlerden almıştır. Eserleri, dönemin Türkçesini bütün incelikleriyle gözler önüne sermekle birlikte Türk milletinin varlık-yokluk mücadelesi verdiği buhranlı günlerde yol gösterici olmuştur (Erol, 2014: 96).

Akif, Doğu ve Batı medeniyetlerini iyi bilen ve her iki medeniyeti de millî potada eriterek yeni bir hâle kavuşturan önemli bir kişiliktir. Ona göre gelişebilmenin ön koşulu, öz kültürden ve değerlerden beslenen fen ve teknik anlayışıdır. Dolayısıyla Müslüman toplumların birleşmesini ve gelişmesini engelleyecek iki unsur olan cehalet ve kavmiyetçiliğe şiddetle karşı çıkan Mehmet Akif'in yerlilik anlayışı; dünyadaki pozitif bilimlere açık, çağdaş bir bakış açısıyla bezenmiştir. Fikir dünyasını din merkezinde yerlilik ve toplumsallık kavramları ile geliştiren şair, Batının türlü sebeplerle Müslüman coğrafyalarını hedef olarak görmesinde aydın kesim ile halk arasındaki uçurumun etkili olduğuna inanmaktadır (İmamoğlu, 2010:165).

Evrensel değerleri millî sınırlar içinde toplumcu bir yaklaşımla yorumlayan Akif, sadece yaşadığı dönemin insanını değil, gelecek nesillerin de nasıl olması gerektiğini Safahat'ın altıncı kitabı olan Âsım'da aktarmıştır: Âsım'ın nesli olarak nitelendirdiği nesilleri; iman, irfan ve ahlâk sahibi, karakterli, vatanına, milletine, dinine sahip çıkan ve bunları korumak, yüceltmek için var gücüyle çalışan bir gençlik olarak tanımlamıştır (Karagöz ve Şimşek, 2017:15).

Âsım bana bak

Yol yakınken geri dön nafile çıkmaz bu sokak

Koşuyorsun be çocuk çarpacak alnın duvara

Dağılır sonra kafan etme çekil bir kenara

Ne demir leblebi meslek bu Ebuzervari

Ömer'in zabıta memuru geleydin bari

(Safahat, s. 442)

Yukarıdaki dizelerde seyyar zaptiyelikle toplumdaki aksaklıkların giderilemeyeceği belirtilmektedir; şair tarafından ideal insanın mutlaka azimli, çalışkan aynı zamanda da ümitvar olması gerektiği aşağıdaki dizelerde vurgulanmaktadır:

Bir gaye-i maksuda şitab eyleyen adem

Tutmuşsa bidayette eğer azmini muhkem

Er geç bulacak sa'y ile dil-hâhını elbet.

Zîrâ bu şu'un-zâr-ı tecellîde, hakîkat,

Tevfík, taharrîye; taharrî ona âşık;

Azminde emel lâzımıdır, gayr-i müfârık. 
$\cdots$

(Safahat, s. 367)

İslam'ın yasakladığı konulardan olan içki ve zinadan şiddetle uzak duran Akif, Mahalle Kahvesi'nde meyhane, kahve gibi yerlerin milletin azmini ve çalışma isteğini olumsuz yönde etkilediğini hatta aile hayatına da darbe vurduğunu aşağıdaki dizelerde dile getirdiği eleştiriler ile ifade etmektedir:

O kahraman babalardan doğan bu nesl-i cebîn

Ne gîrûdâr-ı mâişet bilir, ne kedd-i yemîn.

Azâb içinde kalır sa'yi görse rü'yâda!

Niçin yorulmalı zaten ölümlü dünyada?

Vücut emanet-i hak; doğru hem de cennetlik

Bu kahveler gibi cennet de Müslüman'a gedik

(Uç, 2009)

Türk dünyasında çocuğun baba soyuyla anılmasına bağlı Akif'in daha çok Kosovalı bir Arnavut olarak bilinmesine karşın annesinin Türkistan'ın Buhara şehrinden Anadolu’ya göç eden bir aileye mensup olması, onun Türklerle bağının derin köklere dayandı̆̆ını gösteren başka bir ayrıntıdır. Dolayısıyla etnik olarak Doğu-Batı senteziyle dünyaya gelmiş olan Akif, bu kültürlerin ve i̇slamlığın merkezi bir coğrafyada yaşamış, kavmiyetçiliği tehlikeli bir hastalık olarak görmüş ve Türk Dünyası'nı bir bütün olarak değerlendirmiştir. Akif, Anadolu Türklerinde yaygın bir şekilde görülen dilin ve dinin korunduğu bir coğrafyanın ancak vatan olabileceği fikriyle örtüşen Türkçülük ve İslamcılığın ortak paydasındaki değerler üzerine şiirlerini vücuda getirmiştir. Bu bakımdan XIX. yüzyıl sonları ile XX. yüzyıl başlarında Rusya'daki Müslüman Türk aydınları tarafından yürütülen yenileşme hareketlerinin dayandığı temel değerler ile Akif'teki değerler tam olarak örtüşmektedir. İsmail Gaspıralı, Şihabeddin Hercani, Abdülnâsır Kursâvi, Hüseyin Feyizhâni, Abdulkayyum Nasırî gibi pek çok aydın, Akif'te de olduğu gibi İslam coğrafyalarındaki savaşların, sömürgelerin eğitimle, çalışmakla, millet aşkıyla ve katı bir din anlayışından vazgeçmekle mümkün olacağına inanmaktadırlar. Netice itibarıyla tüm bu aydınlara göre millî birlik ve bilinci oluşturan İslam Birliği'ni sağlamak da son derece önemlidir. Yakın dönem Azerbaycan edebiyatının önemli isimlerinden olan Vahapzâde, Azerbaycan Komünizminin büyük yıkımlarının yaraladığı millet, vatan, dil olgularını sık sık eserlerinde işlemiş, yaşadığı dönemdeki olumsuzlukları derinden hissetmiş ve toplumun maddi, manevi anlamda yaşadığı değişimleri, zorlukları eserlerine yansıtmış toplumcu bir şairdir. Tıpkı Akif'te olduğu gibi Vahapzâde de sanatı toplumdaki aksaklıkları dile getirmeye ve çözümler, çareler aramaya araç olarak görmüştür. Vahapzade, Akif'in büyüklüğünün yerel unsurlara bağlılıktan ve güzel ahlâkından geldiğini belirtmiş; "Ben Akif'in karşısında saygıyla eğiliyorum. Allah ona rahmet eylesin." demiş ve Akif'in kaleminden çıkan İstiklal Marşı'nı da "Buna sadece şiir diyemeyiz, buna vatan, millet uğruna her türlü fedakârlığa hazır olan, hayatın manasını vatana ve millete hizmette gören bir büyük insanın kalbindeki duygularının taşan seli." şeklinde nitelendirmiştir (Gündoğdu, 2009:127-128).

Literatüre bakıldığında Mehmet Akif Ersoy'un tüm yönleriyle irdelendiği pek çok çalışmanın yapıldığı görülmektedir. Mehmet Akif Ersoy'un görüşlerinin sosyolojik analizi (Kır, 1988), Mehmet Akif ve insan (Aktaş, 1989), İstiklal Marşı'mızın tarihî, edebî, dinî ve kültürel kaynakları (Çetin, 2010), Mehmet Akif'in karakteri ve sanatı (Okay, 2008), Mehmet Akif'in poetikası (Şimşek, 2015), İstiklal Marşı ve Mehmet Akif Ersoy (Timurtaş, 2002), İstiklal Marşı'nın söz varlığı üzerinde analitik bir inceleme denemesi (Acar, 2018), İstiklal Marşı'nın noktalaması (Atasoy, 2010), Mehmet Akif Ersoy ve İstiklal Marşı (Canım ve Çalık, 2007), i̇stiklal Marşı ve Akif'i yeniden anlamak (Durmuş, 2013), Mehmet Akif Ersoy'un hayatı ve eserlerinden seçmeler (Gündüzalp, 2008), Millî yürek Mehmet Akif Ersoy'un din ve toplum anlayışı (Kılıç, 2008), İstiklal Marşı besteleri (Sağer, 2010), Türkiye'de Millî Marşın kabulünde güfte ve beste tartışmaları (Yaşar, 2018), isstiklal Marşı'nın temel kavramları (Zavotçu, 2017), İstiklal Marşı Tarihi ve Anlamı (Ayvazoğlu, 1986), İstiklal Marşı Şairimizin İstiklal harbindeki vaazları (Boşnakoğlu, 1981), Atatürk ve Akif (Ergin, 1986), Mehmet Akif'in hayatı-eserleri (Fergan, 1938), Mehmet Akif Ersoy'un dili üzerine (Gökyay, 1986), Akif'in şiirleri ve halka hitap etme düşüncesinden kaynaklanan özellikler (Kurnaz, 1986), Emperyalizme direnen Türk Mehmet Akif Ersoy (Çetin, 2013), Mehmet Akif'in şiirlerinde kadın ve aile temi (Ercilasun, 1987), Mehmet Akif Ersoy'un kadın konusuna yönelik çevirileri ve Safahat'ta kadın duygusu (Karataş, 2009), Mehmet Akif'in şiir dili: Mehmet Akif'te 
medeniyet kavramı (İmamoğlu, 2010), Bir merhamet şairi olarak Mehmet Akif (Baş, 2012), Mehmet Akif Ersoy'un şiirlerinde ilahi adalet ve kötülük meselesi (Çapku, 2017), Mehmet Akif Ersoy'un Meyhane ve Mahalle Kahvesi şiirleri üzerine bir değerlendirme (Aydoğan, 1997), Mehmet Akif Ersoy, Necip Fazıl Kısakürek ve Sezai Karakoç şiirlerinde bir medeniyet ölçüsü olarak Hz. Muhammed (Koçak, 2016), Mehmet Akif'in şiirlerinde tasavvuf: Safahat'ı bir tasavvuf ahlak metni olarak okumak (Demirli, 2011), Mehmet Akif ile ilgili yapılmış çalışmalardan bazılarıdır. Geçmişten günümüze Mehmet Akif Ersoy'un şahsını ve eserlerini çeşitli yönlerden irdeleyen tez, makale, kitap ve bildiri niteliğindeki bu çalışmaların büyük çoğunluğunun Mehmet Akif Ersoy'un eserleri, sanat anlayışı gibi edebî konularda olduğu görülmektedir. Mehmet Akif Ersoy'un şiirlerinin Türkçe öğretiminde kullanımı (Tekşan ve Çelik, 2014), Türkçe öğretiminde yaratıcı yazma becerilerinin geliştirilmesi (Temizkan, 2010), Mehmet Akif Ersoy'un Türk eğitimine katkıları (Özgen, 2013), Üniversite öğrencilerinin İstiklal Marşı algısı (İşcan ve Şimşek, 2012), Mehmet Akif'in Safahat adlı eserinde yer alan şiirlerin çocuk edebiyatı ölçütlerine göre hikâyeleştirilmesi (Temizyürek ve Kansızoğlu, 2016), Üniversite öğrencilerinin İstiklal Marşı'ndaki anahtar kelimeleri bilme durumları (Arslan, 2013) gibi şairin eserlerini ve şahsiyetini değerler eğitimi açısından ele alan çok kıymetli çalışmalar da mevcuttur. Arslan (2013) tarafından yapılan çalışmada, Ağrı İbrahim Çeçen Üniversitesi'nde öğrenim gören öğrencilerin İstiklal Marşı'ndaki anahtar kelimeleri doğru/yanlış bilme durumlarında etkili olan herhangi bir değişkenden bahsedilmemiş; üniversitede değişik bölümlerde öğrenim gören öğrencilerin anahtar kelimeleri doğru/yanlış bilme durumları tespit edilmiştir. Ancak bu çalışmada, hem farklı anahtar kelimeler kullanılmış hem de öğrencilerin bu anahtar kelimeleri doğru/yanlış bilme durumlarında etkili olan cinsiyet, bölüm gibi değişkenlere göre tespitler yapılmıştır. Mehmet Akif'in hem şahsının hem de toplumun hizmetine sunduğu eserlerinin eğitimöğretimin her kademesinde değerler eğitimi açısından incelendiği güncel çalışmalara daha fazla eğilmek gerekmektedir. Türk eğitim politikasının amacı şahsına, vatanına, milletine faydalı işler yapan bireyler yetiştirmek olduğu düşünüldüğünde Mehmet Akif Ersoy'un gerek şahsı gerekse eserleri ile ilgili daha fazla çalışma yapılması gereklidir.

Bu çalışmada aşağıdaki sorulara cevap aranmıştır:

1. İstiklal Marşı'ndaki anahtar kelimelerin lise ve üniversite düzeyindeki öğrenciler tarafından bilinme durumları istatistiksel olarak nasıldır?

2. İstiklal Marşı́ndaki anahtar kelimelerin bilinme durumları kız/erkek öğrencilere göre değişkenlik göstermekte midir?

3. İstiklal Marşı'ndaki anahtar kelimeler öğrencilerin sayısalcı, sözelci, eşit ağırlıkçı olma durumlarına göre değişkenlik göstermekte midir?

4. İstiklal Marşı'nın ilk iki kıtasındaki anahtar kelimeler ile diğer kıtalarındaki anahtar kelimelerin bilinme durumu istatistiksel olarak nasıldır?

5. Her iki kademe, anahtar kelimeleri doğru/yanlış bilme oranları açısından kıyaslandığında ulaşılan sonuçlar nelerdir?

\section{Çalışmanın Modeli}

\section{Yöntem}

Bu çalışma tarama modeline uygun olarak tasarlanmış betimsel bir araştırmadır. Özellikle sosyal bilimler alanında yapılan çalışmalarda sıklıkla başvurulan bir yöntem olan tarama modeli, geçmişte ya da günümüzde var olan bir durumun belirli değişkenler açısından betimlenmesidir. Bu yöntem, evrenin tamamı yerine evreni temsil eden örneklem içerisinde yer alan bireylere yöneltilen soruların cinsiyet, yaş veya sosyoekonomik gibi özellikleri bakımından ilişkilerini inceleyen veriler üzerine temellendirilir (Atalay Mazlum ve Mazlum, 2017:5-6).

\section{Çalışma Grubu}

Bu çalışmada, Kilis ilinin merkezi genel evren olarak belirlenmiştir. Genel evren içinde bulunan Kilis devlet liseleri ve Kilis 7 Aralık Üniversitesi çalışma evreni olarak seçilmiştir. Çalışma grubu ise 20192020 eğitim-öğretim yılı güz döneminde Kilis devlet liselerinde son sınıfta öğrenim gören 111 öğrenci ile Kilis 7 Aralık Üniversitesi'nin farklı bölümlerinde son sınıfta öğrenim gören 111 öğrenci olmak üzere toplamda 222 öğrenciden oluşmaktadır. Araştırmanın çalışma grubu oluşturulurken basit seçkisiz 
yöntem kullanılmıştır. Evreni temsil etme gücü yüksek olan bu yöntemde, evrendeki tüm birimler örneğe seçilmek için bağımsız ve eşit bir şansa sahiptir (Büyüköztürk vd., 2016). Araştırmacı tarafından ayrıca oluşturulan kişisel bilgi formunda; lise ve üniversite öğrencilerinin cinsiyetlerini, yaşlarını, bölümlerini belirlemeye yönelik sorular bulunmaktadır. Lise ve üniversite düzeyindeki öğrencilerin demografik bilgileri Tablo 1 ve Tablo 2'de yer almaktadır:

Tablo 1.

Lise Öğrencilerinin Demografik Bilgileri

\begin{tabular}{cll}
\hline & & $(\mathrm{f})$ \\
\hline \multirow{2}{*}{ Yaş } & 18 & 86 \\
Cinsiyet & 19 & 25 \\
& Kız & 56 \\
& Erkek & 55 \\
& & \\
\hline Bölüm & Sayısal (Matematik-Fen) & 39 \\
& Eşit Ağırlık (Türkçe-Matematik) & 37 \\
& Sözel (Türkçe-Sosyal Bilgiler) & 35 \\
\hline
\end{tabular}

Tablo 1 incelendiğinde çalışmaya katılan lise öğrencilerinin yaş, cinsiyet, bölüm değişkenlerindeki niceliklerin küçük farklarla eşit düzeyde olduğu görülmektedir. Özellikle yaş değişkenleri birbirine çok yakın olduğu için tablolarda yaş ile ilgili bir değerlendirme yapılmamıştır.

Tablo 2.

Üniversite Öğrencilerinin Demografik Bilgileri

\begin{tabular}{clc}
\hline & (f) \\
\hline \multirow{3}{*}{ Yaş } & 22 & 44 \\
& 23 & 51 \\
& 24 & 4 \\
& 25 & 4 \\
& 26 & 5 \\
& 27 & 3 \\
\hline Cinsiyet & Kız & 74 \\
& Erkek & 37 \\
& & \\
\hline Bölüm & Sayısal (Matematik-Fen) & 37 \\
& Eşit Ağırlık (Türkçe-Matematik) & 14 \\
& Sözel (Türkçe-Sosyal Bilgiler) & 60 \\
& & \\
\hline
\end{tabular}

Tablo 2'de çalışma grubunda yer alan üniversite öğrencilerinin 37 'sinin sayısal bölümlerde, 60'ının sözel bölümlerde, 14'ünün ise eşit ağırlık temelli bölümlerde olduğu görülmektedir. Çalışmaya katılan üniversite öğrencilerinin ağırlıklı olarak sözel bölümlerden oldukları ve kız öğrencilerin erkek öğrencilere göre sayıca daha fazla oldukları saptanmıştır.

\section{Veri Toplama Araçları}

Çalışmada, lise ve üniversite düzeyindeki öğrencilerin İstiklal Marşı́ndaki bazı anahtar kelimeleri bilme durumları sayısal verilerden yola çıkılarak betimsel açıdan çözümlenmiştir. Söz konusu anahtar kelimeler belirlenirken Türkçe Eğitimi ile Türk Dili ve Edebiyatı bölümlerinde görev yapan iki uzmandan görüş alınmıştır. Uzman görüşleri doğrultusunda İstiklal Marşı'nın tüm kıtalarından belirlenen toplamda 22 adet anahtar kelimenin yazıldığı form ile İstiklal Marşı'nın on kıtasının yer aldığı 

Örneği)

fotokopi öğrencilere dağıtılmıştır. Öğrencilerden belli bir süre içinde formdaki anahtar kelimelerin İstiklal Marşı'nda geçtiği yere göre anlamlarını yazmaları istenmiştir. Böylelikle elde edilen veriler, frekans ve yüzde değerleri bakımından çözümlenmiştir. Ulaşılan sonuçlar, tablo ve yorumları ile sunulmuştur. Görüşme formundaki anahtar kelimelerin anlamları; Alev (2014), Arslan (2013), Çetin (2014), Gündüzalp (2008) tarafından yapılan çalışmalardaki açıklamalar ve Türkçe Sözlük (2005) dikkate alınarak belirlenmiştir. Bu anahtar kelimeler ve anlamları şu şekildedir:

Tablo 3.

Istiklal Marşı'ndaki Anahtar Kelimeler ve Anlamları

\begin{tabular}{ll}
\hline Anahtar Kelime & Anahtar Kelimenin Anlamı \\
\hline Sancak (1) & Bayrak, liva. \\
Sönmeden (1) & Parlaklığını, ışığını yitirmeden. \\
Ocak (1) & Ev, aile, soy. \\
Irkıma (2) & Kalıtımsal olarak ortak özelliklere sahip insanlar topluluğu, soy. \\
Celal (2) & Öfke, kızgınlık. \\
Ezel (3) & Başlangıcı belli olmayan zaman, öncesizlik. \\
Bent (3) & Set. \\
Garp (4) & Batı. \\
Afak (4) & Ufuklar. \\
Serhat (4) & Sınır boyu. \\
Hayâsızca (5) & Utanması olmaksızın, sıkılmaksızın. \\
Alçaklara (5) & Bile bile en kötü, en ahlaksızca davranışlarda bulunan, namert, hain. \\
İncitme (6) & Kötü söz veya davranışla birini kırmak, üzmek. \\
Şüheda (7) & Şehitler. \\
Cüda (7) & Yurt, baba ocağı gibi çok sevilen şeylerden ayrılmış olan, uzak kalmış olan. \\
Mabet (8) & Tapınak (Cami). \\
Şehadet (8) & Yüksek bir ülkü uğrunda ölme, şehit olma. \\
Vecd (9) & Sevgi veya heyecandan doğan coşkunluk, kendinden geçme, esrime. \\
Ceriham (9) & Yara. \\
Ruh-ı mücerret (9) & Maddesiz (soyut) ruh. \\
İzmihlal (10) & Yıkılma, çökme. \\
Şafak (10) & Güneş doğmadan az önce beliren aydınlık.
\end{tabular}

\section{Verilerin Toplanması}

Çalışma verilerinin toplanması için evrende yer alan $111^{\prime} i$ lise son sınıf öğrencisi, $111^{\prime} i$ de üniversite son sınıf öğrencisi olmak üzere toplam 222 öğrenciye kişisel bilgi formu ve i̇stiklal Marşı'ndaki bazı anahtar kelimelerin yer aldığı form ('̇stiklal Marşı'nın on kıtasının yer aldığı bir nüsha ile birlikte) uygulanmıştır.

\section{Verilerin Analizi}

Çalışmada elde edilen veriler, betimsel analiz tekniği ile okuyucunun anlayabileceği ve gerektiğinde kullanabileceği bir formda sunulmuştur. Öncelikle lise son sınıf grubunda yer alan öğrenciler, sözel/sayısal/eşit ağırlık şeklinde bölümlerine uygun bir şekilde tasniflenmiş; her bölüme ait tabloda yer alan anahtar kelimelerin kız/erkek-doğru/yanlış bilme değişkenlerine göre frekansları belirlenmiştir. Her bölümün anahtar kelimeler ile ilgili cevapları, işaret edilen değişkenlere göre saptandıktan sonra bölüm farkı gözetmeksizin hazırlanan müstakil bir tabloda kız/erkek öğrencilerin anahtar kelimeleri doğru/yanlış bilme durumlarına ait frekanslar genel bir çerçevede aktarılmış ve yorumlanmıştır. Lise öğrencileri için yapılan bu işlemler, aynı şekilde üniversite öğrencileri için de uygulanmıştır. Neticede çeşitli değişkenlere bağı oluşturulan istatistiki veriler, lise ve üniversite öğrencileri açısından karşılaştırmalı olarak ayrıca değerlendirilmiştir. 


\section{Araştırma ve Yayın Etiği}

Bu çalışmada "Yükseköğretim Kurumları Bilimsel Araştırma ve Yayın Etiği Yönergesi" kapsamında uyulması belirtilen tüm kurallara uyulmuştur. Yönergenin ikinci bölümü olan "Bilimsel Araştırma ve Yayın Etiğine Aykırı Eylemler" başlığı altında belirtilen eylemlerden hiçbiri gerçekleştirilmemiştir.

\section{Bulgular}

Çalışma bulguları, lise son sınıf ve üniversite son sınıf öğrencilerinin İstiklal Marşı'nda yer alan toplam 22 adet anahtar kelimedeki başarı düzeyleri ve bu düzeylerin cinsiyet, bölüm gibi değişkenlere göre içerdiği farklııkların istatistiksel değerlendirmelerinden oluşmaktadır.

İstiklal Marşı'ndaki Anahtar Kelimelerin Lise Öğrencileri Tarafından Bilinme Durumları

Tablo 4.

İstiklal Marşı'ndaki Anahtar Kelimelerin Lise/Sözel Bölümdeki Öğrenciler Tarafından Bilinme Durumları

\begin{tabular}{lcccc}
\hline Anahtar Kelime & \multicolumn{2}{c}{ Doğru Bilme } & \multicolumn{2}{c}{ Yanlış Bilme } \\
\hline Sancak & Kız & Erkek & Kız & Erkek \\
Sönmeden & 10 & 15 & 8 & 2 \\
Ocak & 13 & 14 & 5 & 3 \\
Irkıma & 14 & 10 & 4 & 7 \\
Celal & 15 & 14 & 3 & 3 \\
Ezel & 4 & 9 & 14 & 8 \\
Bent & 10 & 12 & 8 & 5 \\
Garp & 3 & 5 & 15 & 12 \\
Afak & 7 & 5 & 11 & 12 \\
Serhat & 3 & 4 & 15 & 13 \\
Hayâsızca & 6 & 7 & 12 & 10 \\
Alçaklara & 6 & 10 & 12 & 7 \\
Incitme & 12 & 13 & 6 & 4 \\
Şüheda & 13 & 13 & 5 & 4 \\
Cüda & 5 & 9 & 13 & 8 \\
Mabet & 2 & 4 & 16 & 13 \\
Şehadet & 3 & 6 & 15 & 11 \\
Vecd & 5 & 7 & 13 & 10 \\
Ceriham & 3 & 3 & 15 & 14 \\
Ruh-ı mücerret & 3 & 2 & 15 & 15 \\
İzmihlal & 2 & 3 & 16 & 14 \\
Şafak & 2 & 2 & 16 & 15 \\
& 8 & 14 & 10 & 3
\end{tabular}

Tablo 4'te lise/sözel bölümde okuyan 18'i kız, 17'si erkek olmak üzere toplam 35 öğrencinin İstiklal Marşı'ndaki anahtar kelimeleri doğru/yanlış bilme durumuna ilişkin veriler yer almaktadır. Buna göre İstiklal Marşı'nın ilk iki kıtasındaki anahtar kelimelerin bilinme düzeyinin diğer kıtalardaki anahtar kelimelerin bilinme düzeyinden çok daha yüksek olduğu görülürken celal kelimesinin bilinme düzeyinin sancak, sönmeden, ocak, ırkıma kelimelerinin bilinme düzeylerinden daha düşük olduğu dikkat çekmektedir. Celal kelimesinde kız/erkek öğrencilerin kelimeleri bilmeme düzeylerinin eş durumda olduğu söylenebilir. İstiklal Marşı'nın üçüncü, dördüncü, beşinci ve altıncı kıtalarında yer alan bent, garp, afak, serhat kelimelerinde kız/erkek öğrencilerin başarı düzeyleri ezel, alçak ve incitme kelimelerindeki başarı düzeylerine oranla daha düşüktür. Tablo genelinde kız/erkek öğrencilerde başarı durumunun en düşük düzeyde olduğu kelimeler ise İstiklal Marşı́nın yedinci, sekizinci, dokuzuncu ve onuncu kıtalarındaki anahtar kelimeler -şafak hariç- olarak görülmektedir. 
İstiklal Marşı'nın Anlaşılma Düzeyinin Tespitine Yönelik Betimsel Bir Çalışma (Lise ve Üniversite Öğrencileri Örneği)

Tablo 5.

istiklal Marşı'ndaki Anahtar Kelimelerin Lise/Sayısal Bölümdeki Öğrenciler Tarafından Bilinme Durumları

\begin{tabular}{lcccc}
\hline Anahtar Kelime & \multicolumn{2}{c}{ Doğru Bilme } & \multicolumn{2}{c}{ Yanlış Bilme } \\
\hline & Kız & Erkek & Kız & Erkek \\
\hline Sancak & 7 & 9 & 12 & 11 \\
Sönmeden & 9 & 12 & 10 & 8 \\
Ocak & 12 & 6 & 7 & 14 \\
Irkıma & 14 & 8 & 5 & 12 \\
Celal & 3 & 4 & 16 & 16 \\
Ezel & 6 & 5 & 13 & 15 \\
Bent & 3 & 4 & 16 & 16 \\
Garp & 5 & 3 & 14 & 17 \\
Afak & 2 & 2 & 17 & 18 \\
Serhat & 5 & 5 & 14 & 15 \\
Hayâsızca & 3 & 5 & 16 & 15 \\
Alçaklara & 13 & 9 & 6 & 11 \\
Incitme & 12 & 12 & 7 & 8 \\
Şüheda & 3 & 6 & 16 & 14 \\
Cüda & 1 & 1 & 18 & 19 \\
Mabet & 4 & 4 & 15 & 16 \\
Şehadet & 5 & 14 & 18 \\
Vecd & 2 & 3 & 17 & 17 \\
Ceriham & 1 & 1 & 18 & 19 \\
Ruh-ı mücerret & 1 & - & 18 & 20 \\
İzmihlal & 1 & - & 18 & 20 \\
Şafak & 6 & 9 & 13 & 11 \\
\hline & & & & \\
\hline
\end{tabular}

Tablo 5'te lise/sayısal bölümde okuyan 19'u kız, 20'si erkek olmak üzere toplam 39 öğrencinin İstiklal Marşı'ndaki anahtar kelimeleri doğru/yanlış bilme durumuna ilişkin veriler yer almaktadır. Tabloya göre İstiklal Marşı'nın ilk iki kıtasında yer alan anahtar kelimelerden celal kelimesi hariç sancak, sönmeden, ocak, ırkıma kelimelerinin bilinme düzeylerinin diğer kıtalardaki kelimelerin bilinme düzeylerine oranla daha yüksek olduğu saptanmıştır. Celal kelimesini bilmeme durumunun kız/erkek öğrencilerde hemen hemen eş düzeyde olduğu söylenebilir. İstiklal Marşı'nın üçüncü, dördüncü, beşinci ve altıncı kıtalarında yer alan anahtar kelimelerden alçak ve incitme dışındaki ezel, bent, garp, afak, serhat, hayasızca kelimelerinde tüm öğrencilerin başarı düzeyleri, ilk iki kıtadaki anahtar kelimelere göre daha düşük seviyededir ve mevcut bilmeme durumunun kız/erkek öğrencilerde eş düzeyde olduğu söylenebilir. Tablo genelinde başarı düzeyinin en düşük olduğu kelimeler i̇stiklal Marşı'nın yedinci, sekizinci, dokuzuncu ve onuncu kıtalarında yer alan cüda, ceriham, ruh-ı mücerret ve izmihlal'dir. Hatta ceriham ve ruh-ı mücerret kelimelerini doğru açıklayan erkek öğrenci olmamıştır. Tablo genelinde kız ve erkek öğrencilerin kelimeleri doğru/yanlış bilme düzeyleri eşit gibi görünmekle birlikte ocak, ırk, alçak kelimelerinin kız öğrenciler tarafından bilinme düzeylerinin erkek öğrencilerin bu kelimeleri bilme düzeylerine oranla daha yüksek olduğu görülmektedir. 
Tablo 6.

Istiklal Marşı'ndaki Anahtar Kelimelerin Lise/Eşit Ağırlık Bölümdeki Öğrenciler Tarafından Bilinme Durumları

\begin{tabular}{lcccc}
\hline Anahtar Kelime & \multicolumn{2}{c}{ Doğru Bilme } & \multicolumn{2}{c}{ Yanlış Bilme } \\
\hline & Kız & Erkek & Kız & Erkek \\
\hline Sancak & 8 & 10 & 11 & 8 \\
Sönmeden & 14 & 12 & 5 & 6 \\
Ocak & 10 & 8 & 9 & 10 \\
Irkıma & 13 & 12 & 6 & 6 \\
Celal & 4 & 7 & 15 & 11 \\
Ezel & 4 & 10 & 15 & 8 \\
Bent & 4 & 4 & 15 & 14 \\
Garp & 7 & 4 & 12 & 14 \\
Afak & 3 & 3 & 16 & 15 \\
Serhat & 5 & 8 & 14 & 10 \\
Hayâsızca & 7 & 10 & 12 & 8 \\
Alçaklara & 12 & 12 & 7 & 6 \\
İncitme & 15 & 12 & 4 & 6 \\
Şüheda & 5 & 7 & 14 & 11 \\
Cüda & 3 & 2 & 16 & 16 \\
Mabet & 4 & 5 & 15 & 13 \\
Şehadet & 5 & 14 & 13 \\
Vecd & 3 & 2 & 16 & 16 \\
Ceriham & 2 & 1 & 17 & 17 \\
Ruh-ı mücerret & 1 & 2 & 18 & 16 \\
İzmihlal & 1 & 1 & 18 & 17 \\
Şafak & 11 & 10 & 8 & 8 \\
& & & &
\end{tabular}

Tablo 6'da lise/eşit ağılık bölümünde okuyan $19^{\prime}$ u kız, 18'i erkek olmak üzere toplam 37 öğrencinin İstiklal Marşı'ndaki anahtar kelimeleri doğru/yanlış bilme durumuna ilişkin veriler yer almaktadır. Tabloya göre i̇stiklal Marşı'nın ilk iki kıtasındaki anahtar kelimelerin bilinme düzeyleri diğer kıtalarda yer alan kelimelerin bilinme düzeylerine oranla daha yüksektir. Yalnız sözel ve sayısal bölümü öğrencilerinde olduğu gibi eşit ağırlık bölümü öğrencilerinde de ikinci kıtada yer alan celal kelimesini bilmeme düzeyinin yüksekliği dikkat çekmektedir. Üç bölümde de kız öğrencilerin celal kelimesini bilme düzeylerinin erkek öğrencilerin bu kelimeleri bilme düzeylerine göre daha düşük olduğu görülmektedirler. İstiklal Marşı'nın üçüncü, dördüncü, beşinci ve altıncı kıtalarında en az bilinen anahtar kelimeler afak, serhat, bent, ezel, garp iken en çok bilinen anahtar kelimeler ise alçak ve incitme şeklindedir. Az bilinen kelimelerdeki başarısızlık düzeyi kız/erkek öğrencilerde neredeyse eşit görünürken ezel, serhat, hayasızca kelimelerinde erkekler, kızlara oranla daha başarılılardır. Diğer tablolarda olduğu gibi lise/eşit ağırlık tablosunda da başarı düzeyinin en düşük olduğu kelimeler yedinci, sekizinci, dokuzuncu ve onuncu kıtalarda yer alan cüda, vecd, ceriham, ruh-ı mücerret ve izmihlal kelimeleridir. Söz konusu kelimelerde kız/erkek öğrencilerin başarısızlık düzeyleri aynı iken yine bu kıtalarda yer alan şüheda, mabet, şehadet kelimeleri diğer kelimelere göre daha çok bilinen kelimelerdir ve bu kelimelerin kız/erkek öğrenciler tarafından bilinme düzeyleri de eş durumdadır. Tablo geneline bakıldığında lise/eşit ağırlık kız/erkek öğrencilerin anahtar kelimelerdeki başarı düzeylerinin herhangi bir değişkene bağı olmadan anahtar kelimelere göre farklılık gösterdiği söylenebilir. 
İstiklal Marşı'nın Anlaşılma Düzeyinin Tespitine Yönelik Betimsel Bir Çalışma (Lise ve Üniversite Öğrencileri Örneği)

Tablo 7.

İstiklal Marşı'ndaki Anahtar Kelimelerin Lise Öğrencileri Tarafından Bilinme Durumları

\begin{tabular}{lcccc}
\hline Anahtar Kelime & \multicolumn{2}{c}{ Doğru Bilme } & \multicolumn{2}{c}{ Yanlış Bilme } \\
\hline & Kız & Erkek & Kız & Erkek \\
\hline Sancak & 25 & 34 & 31 & 21 \\
Sönmeden & 36 & 38 & 20 & 17 \\
Ocak & 36 & 24 & 20 & 31 \\
Irkıma & 42 & 34 & 14 & 21 \\
Celal & 11 & 20 & 45 & 35 \\
Ezel & 20 & 27 & 36 & 28 \\
Bent & 10 & 13 & 46 & 42 \\
Garp & 19 & 12 & 37 & 43 \\
Afak & 8 & 9 & 48 & 46 \\
Serhat & 16 & 20 & 40 & 35 \\
Hayâsızca & 16 & 25 & 40 & 30 \\
Alçaklara & 37 & 34 & 19 & 21 \\
Incitme & 40 & 37 & 16 & 18 \\
Şüheda & 13 & 22 & 43 & 33 \\
Cüda & 6 & 7 & 50 & 48 \\
Mabet & 11 & 15 & 45 & 40 \\
Şehadet & 15 & 14 & 41 & 41 \\
Vecd & 8 & 8 & 48 & 47 \\
Ceriham & 6 & 5 & 50 & 50 \\
Ruh-ı mücerret & 4 & 5 & 52 & 50 \\
İzmihlal & 4 & 3 & 52 & 52 \\
Şafak & 25 & 33 & 31 & 22 \\
& & & &
\end{tabular}

Tablo 7'de lise düzeyinde 56'sı kız, 55'i erkek olmak üzere toplam 111 öğrencinin ístiklal Marşı'ndaki anahtar kelimeleri doğru/yanlış bilme durumu sayısal verilerle listelenmiştir. Tabloda da görüldüğü üzere kız öğrenciler ile erkek öğrencilerin anahtar kelimelerdeki başarı düzeylerinin, bazı kelimelerdeki farklııklar istisna tutulursa eş durumda olduğu söylenebilir. Celal hariç i̇stiklal Marşı'nın ilk iki kıtasında yer alan sancak, sönmeden, ocak, ırk kelimeleri, kız/erkek öğrenciler tarafından en çok bilinen kelimelerdir. Yine beşinci, altıncı kıtalarda yer alan alçak, incitme kelimeleri de kı/erkek öğrenciler tarafından en çok bilinen kelimeler arasındadır. En az bilinen kelimeler dördüncü kıtadaki afak, yedinci kıtadaki cüda, dokuzuncu kıtadaki vecd, ceriham, ruh-ı mücerret ve onuncu kıtadaki izmihlal kelimeleridir. 


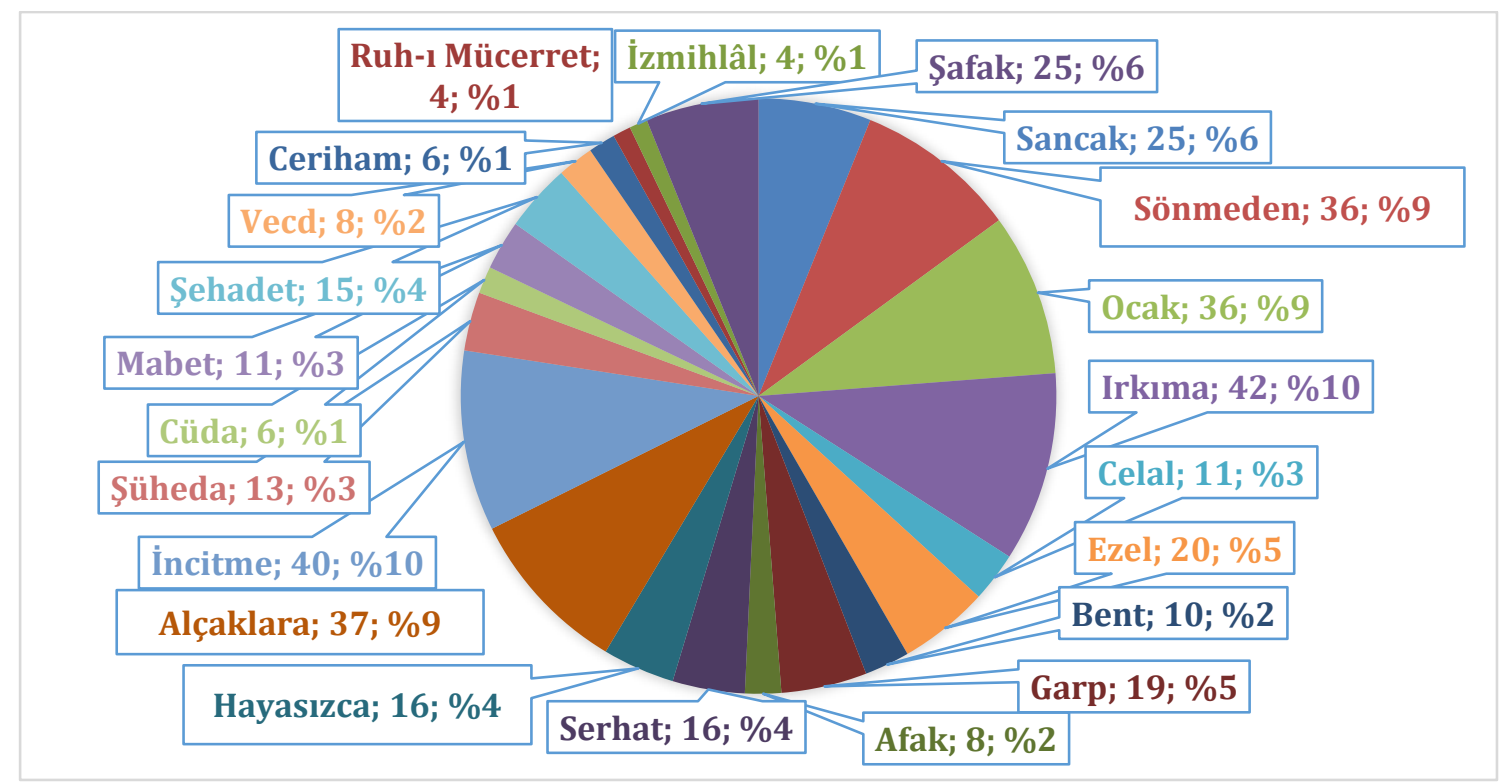

Grafik 1. Lise/Kız Öğrenciler Tarafından Doğru Bilinen Anahtar Kelimelerin Oransal Dağılımı

Grafik 1'de lise/kız öğrencilerin İstiklal Marşı'ndaki anahtar kelimeleri doğru bilme durumları yüzdelik değerler üzerinden gösterilmiştir.

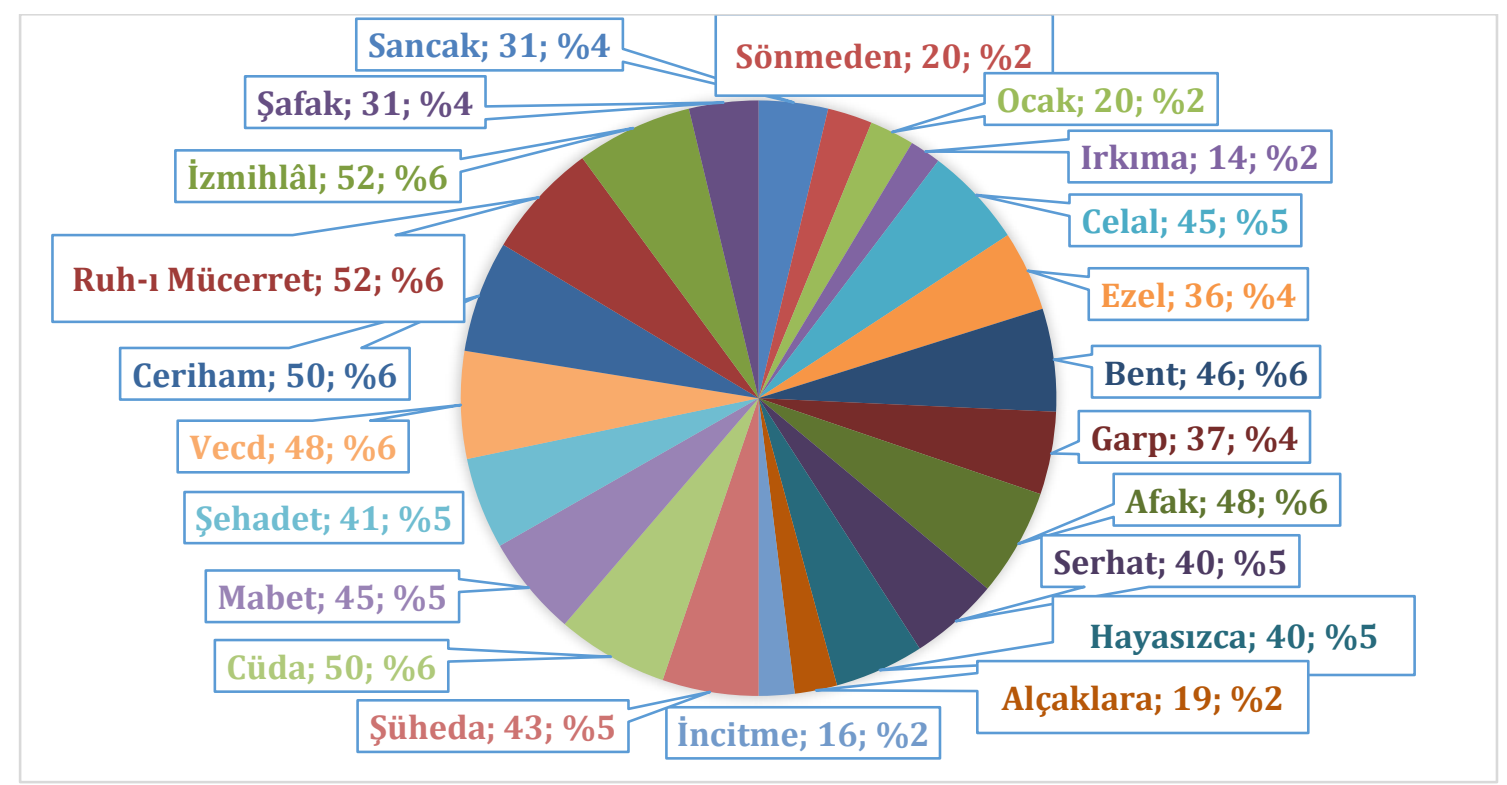

Grafik 2. Lise/Kız Öğrenciler Tarafından Yanlış Bilinen Anahtar Kelimelerin Oransal Dağılımı

Grafik 2'de lise/kız öğrencilerin İstiklal Marşı'ndaki anahtar kelimeleri yanlış bilme durumları yüzdelik değerler üzerinden gösterilmiştir.

Grafik 1 ve Grafik 2'deki lise/kız öğrencilere ait sayısal veriler topluca değerlendirilmiş ve bu verilerden yola çıkılarak Tablo 8 oluşturulmuştur: 
İstiklal Marşı'nın Anlaşılma Düzeyinin Tespitine Yönelik Betimsel Bir Çalışma (Lise ve Üniversite Öğrencileri Örneği)

Tablo 8.

Lise/Kız Öğrencilerin Istiklal Marşı'ndaki Anahtar Kelimeleri Doğru/Yanlış Bilme Frekans ve Yüzdelikleri

\begin{tabular}{lclc}
\hline \multicolumn{2}{c}{ Doğru Bilme Frekans ve Yüzdelik } & \multicolumn{2}{c}{ Yanlış Bilme Frekans ve Yüzdelik } \\
\hline Kelime & Frekans/Yüzdelik & Kelime & Frekans/Yüzdelik \\
\hline Irkıma & $42, \% 10$ & İzmihlal & $52, \% 6$ \\
İncitme & $40, \% 10$ & Ruh-ı Mücerret & $52, \% 6$ \\
Alçaklara & $37, \% 9$ & Ceriham & $50, \% 6$ \\
Ocak & $36, \% 9$ & Vecd & $50, \% 6$ \\
Sönmeden & $36, \% 9$ & Cüda & $50, \% 6$ \\
Sancak & $25, \% 6$ & Afak & $48, \% 6$ \\
Şafak & $25, \% 6$ & Bent & $46, \% 6$ \\
Ezel & $20 \%$ & Mabed & $45, \% 5$ \\
Garp & $19, \% 5$ & Celal & $45, \% 5$ \\
Serhat & $16, \% 4$ & Şüheda & $43, \% 5$ \\
Hayasızca & $16, \% 4$ & Şehadet & $41, \% 5$ \\
Şehadet & $15, \% 4$ & Serhat & $40, \% 5$ \\
Şüheda & $13, \% 3$ & Hayasızca & $40, \% 5$ \\
Celal & $11, \% 3$ & Garp & $37, \% 4$ \\
Mabed & $11, \% 3$ & Ezel & $36, \% 4$ \\
Bent & $10, \% 2$ & Şafak & $31, \% 4$ \\
Afak & $8, \% 2$ & Sancak & $31, \% 4$ \\
Vecd & $8, \% 2$ & Sönmeden & $20, \% 2$ \\
Cüda & $6, \% 1$ & Ocak & $20, \% 2$ \\
Ceriham & $6, \% 1$ & Alçaklara & $19, \% 2$ \\
Ruh-ı Mücerret & $4, \% 1$ & Incitme & $16, \% 2$ \\
İzmihlal & $4, \% 1$ & Irkıma & $14, \% 2$ \\
\hline
\end{tabular}

Tablo 8'de lise/kız öğrencilerin i̇stiklal Marşı'ndaki anahtar kelimeleri doğru/yanlıs bilme durumlarına ait sayısal veriler, frekans/yüzdelik değerleri ile birlikte çoktan aza doğru sıralanarak aktarılmıştır. Tablodaki verilere göre lise/kız öğrenciler tarafından en çok doğru bilinen anahtar kelimeler ırkıma, incitme, alçaklara, ocak, sönmeden iken en çok yanlış bilinen anahtar kelimeler ise izmihlal, ruh-ı mücerret, ceriham, vecd, cüda, afak, bent şeklindedir.

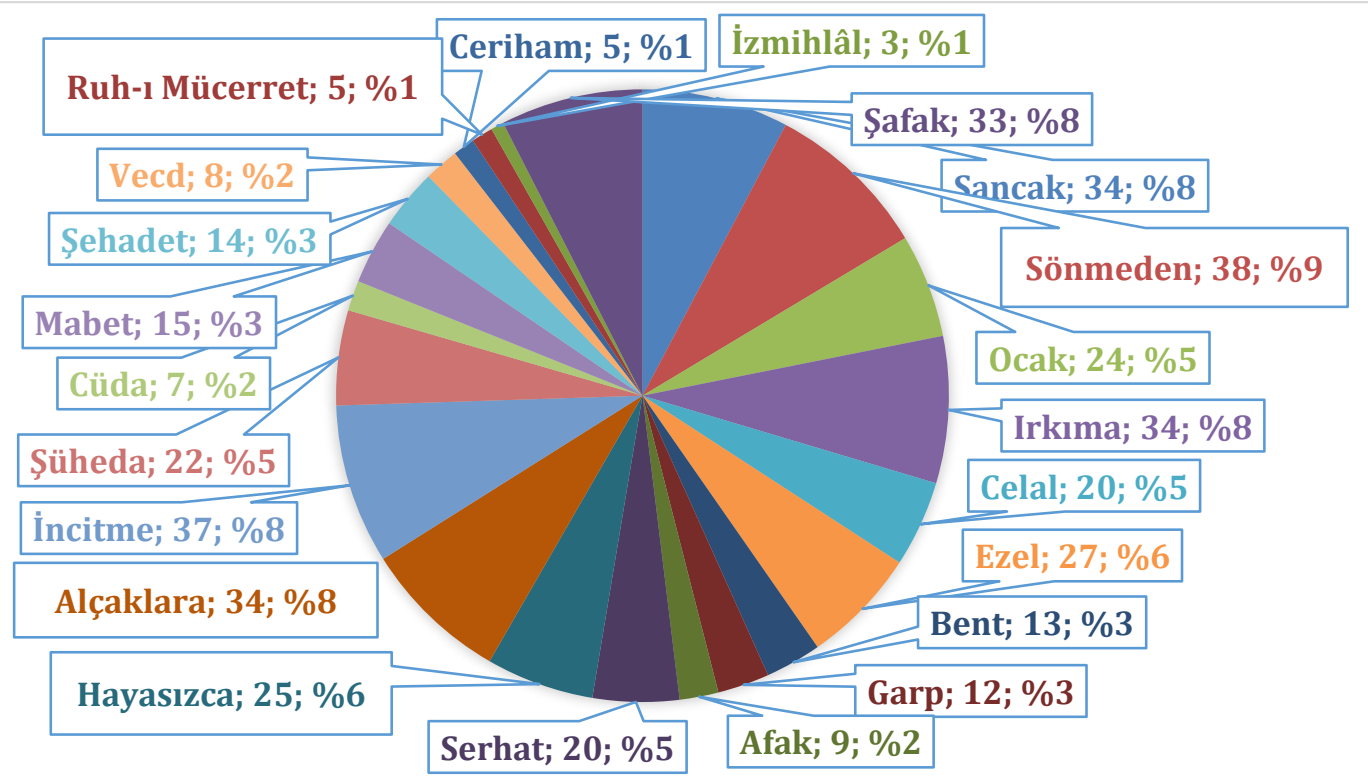

Grafik 3. Lise/Erkek Öğrenciler Tarafından Doğru Bilinen Anahtar Kelimelerin Oransal Dağılımı 
Grafik 3'te lise/erkek öğrencilerin İstiklal Marşı'ndaki anahtar kelimeleri doğru bilme durumları yüzdelik değerler üzerinden gösterilmiştir.

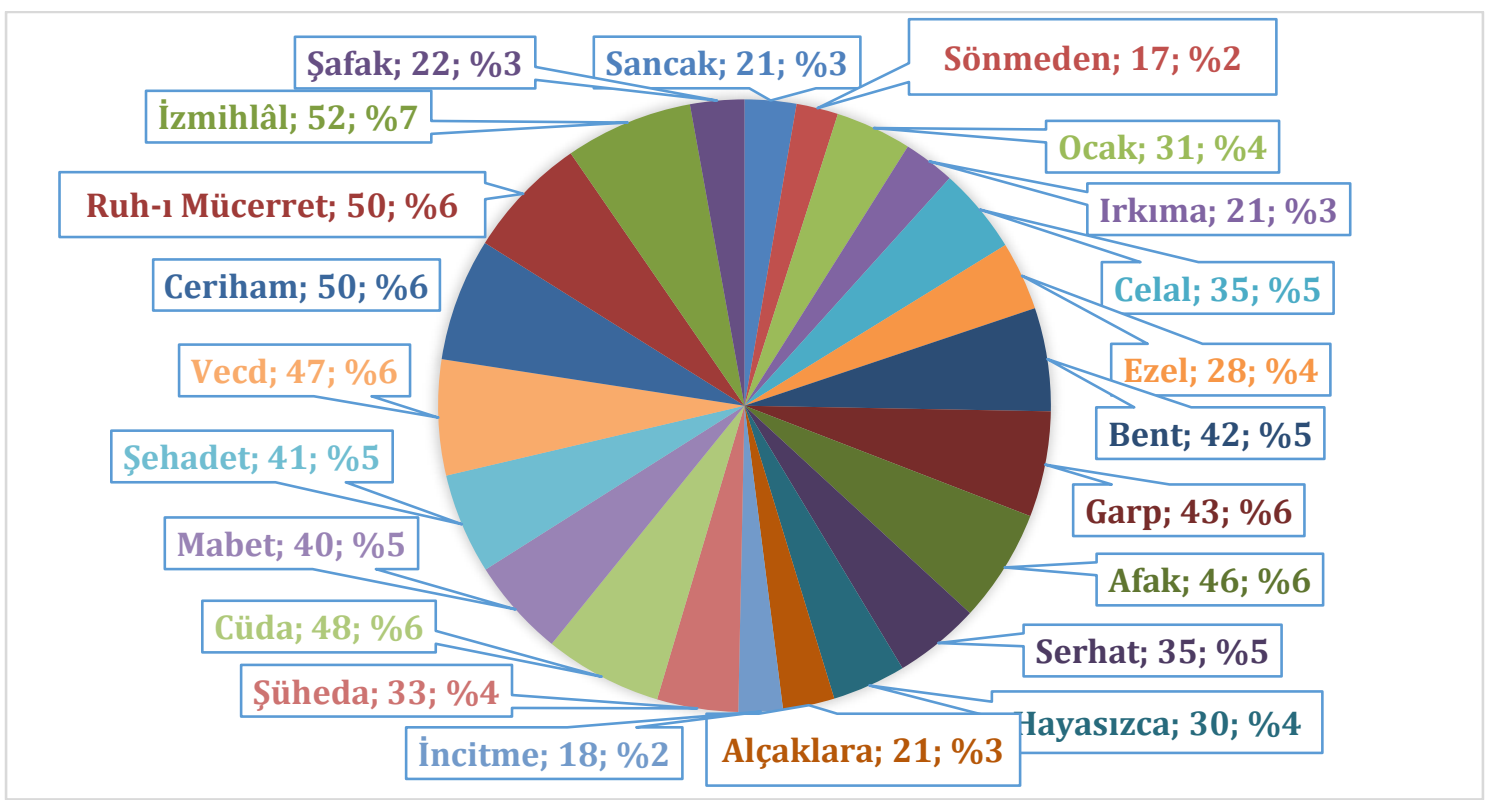

Grafik 4. Lise/Erkek Öğrenciler Tarafından Yanlış Bilinen Anahtar Kelimelerin Oransal Dağılımı

Grafik 4'te lise/erkek öğrencilerin İstiklal Marşı'ndaki anahtar kelimeleri yanlış bilme durumları yüzdelik değerler üzerinden gösterilmiştir.

Grafik 3 ve Grafik 4'teki lise/erkek öğrencilere ait sayısal veriler topluca değerlendirilmiş ve bu verilerden yola çıkılarak Tablo 9 oluşturulmuştur:

Tablo 9.

Lise/Erkek Öğrencilerin Istiklal Marşı'ndaki Anahtar Kelimeleri Doğru/Yanlış Bilme Frekans ve Yüzdelikleri

\begin{tabular}{lclc}
\hline \multicolumn{2}{c}{ Doğru Bilme Frekans ve Yüzdelik } & \multicolumn{2}{c}{ Yanlış Bilme Frekans ve Yüzdelik } \\
\hline Kelime & Frekans/Yüzdelik & Kelime & Frekans/Yüzdelik \\
\hline Sönmeden & $38, \% 9$ & İzmihlal & $52, \% 7$ \\
İncitme & $37, \% 8$ & Ruh-ı Mücerret & $50, \% 6$ \\
Sancak & $34, \% 8$ & Ceriham & $50, \% 6$ \\
Irkıma & $34, \% 8$ & Cüda & $48, \% 6$ \\
Alçaklara & $34, \% 8$ & Vecd & $47, \% 6$ \\
Şafak & $33, \% 8$ & Afak & $46, \% 6$ \\
Ezel & $27, \% 6$ & Garp & $43, \% 6$ \\
Hayasızca & $25, \% 6$ & Bent & $42, \% 5$ \\
Ocak & $24, \% 5$ & Şehadet & $41, \% 5$ \\
Şüheda & $22, \% 5$ & Mabed & $40, \% 5$ \\
Serhat & $20, \% 5$ & Serhat & $35, \% 5$ \\
Celal & $20, \% 5$ & Celal & $35, \% 5$ \\
Mabed & $15, \% 3$ & Şüheda & $33, \% 4$ \\
Şehadet & $14, \% 3$ & Ocak & $31, \% 4$ \\
Bent & $13, \% 3$ & Hayasızca & $30, \% 4$ \\
Garp & $12, \% 3$ & Ezel & $28, \% 4$ \\
Afak & $9, \% 2$ & Şafak & $22, \% 3$ \\
Vecd & $8, \% 2$ & Irkıma & $21, \% 3$ \\
Cüda & $7, \% 2$ & Sancak & $21, \% 3$ \\
Ceriham & $5, \% 1$ & Alçaklara & $21, \% 3$ \\
\hline
\end{tabular}


İstiklal Marşı'nın Anlaşılma Düzeyinin Tespitine Yönelik Betimsel Bir Çalışma (Lise ve Üniversite Öğrencileri Örneği)

\begin{tabular}{llll}
\hline Ruh-ı Mücerret & $5, \% 1$ & Incitme & $18, \% 2$ \\
İzmihlal & $3, \% 1$ & Sönmeden & $17, \% 2$
\end{tabular}

Tablo 9'da lise/erkek öğrencilerin İstiklal Marşı'ndaki anahtar kelimeleri doğru/yanlış bilme durumlarına ait sayısal veriler frekans/yüzdelik değerleri ile birlikte çoktan aza doğru sıralanarak aktarılmıştır. Tablodaki verilere göre lise/erkek öğrenciler tarafından en çok doğru bilinen anahtar kelimeler sönmeden, incitme, sancak, ırkıma, alçaklara, şafak iken en çok yanlış bilinen anahtar kelimeler ise izmihlal, ruh-ı mücerret, ceriham, cüda, vecd, afak, garp şeklindedir.

\section{İstiklal Marşı'ndaki Anahtar Kelimelerin Üniversite Öğrencileri Tarafından Bilinme Durumları}

Tablo 10.

Istiklal Marşı'ndaki Anahtar Kelimelerin Üniversite Sözel Bölüm Öğrencileri Tarafından Bilinme Durumları

\begin{tabular}{|c|c|c|c|c|}
\hline \multirow[t]{2}{*}{ Anahtar Kelime } & \multicolumn{2}{|c|}{ Doğru Bilme } & \multicolumn{2}{|c|}{ Yanlış Bilme } \\
\hline & KIz & Erkek & Kız & Erkek \\
\hline Sancak & 30 & 15 & 10 & 5 \\
\hline Sönmeden & 35 & 18 & 5 & 2 \\
\hline Ocak & 28 & 16 & 12 & 4 \\
\hline Irkıma & 40 & 18 & - & 2 \\
\hline Celal & 30 & 15 & 10 & 5 \\
\hline Ezel & 35 & 17 & 5 & 3 \\
\hline Bent & 25 & 9 & 15 & 11 \\
\hline Garp & 31 & 16 & 9 & 4 \\
\hline Afak & 20 & 11 & 20 & 9 \\
\hline Serhat & 35 & 17 & 5 & 3 \\
\hline Hayâsızca & 33 & 16 & 7 & 4 \\
\hline Alçaklara & 35 & 18 & 5 & 2 \\
\hline İncitme & 36 & 17 & 4 & 3 \\
\hline Şüheda & 25 & 12 & 15 & 8 \\
\hline Cüda & 15 & 7 & 25 & 13 \\
\hline Mabet & 25 & 16 & 15 & 4 \\
\hline Şehadet & 27 & 17 & 13 & 3 \\
\hline Vecd & 10 & 4 & 30 & 16 \\
\hline Ceriham & 8 & 5 & 32 & 15 \\
\hline Ruh-ı mücerret & 10 & 4 & 30 & 16 \\
\hline İzmihlal & 7 & 3 & 33 & 17 \\
\hline Şafak & 40 & 16 & - & 4 \\
\hline
\end{tabular}

Tablo 10'da üniversite/sözel düzeyindeki 40'ı kız, 20'si erkek olmak üzere toplam 60 öğrencinin İstiklal Marşı'ndaki anahtar kelimeleri doğru/yanlış bilme durumuna ilişkin veriler yer almaktadır. Üniversite grubunda neredeyse tüm bölümlerde kız öğrencilerin erkek öğrencilerden sayıca fazla olması -özellikle sözel bölüm ağırlıklı eğitim fakültesinde- eşit sayıda kız ve erkek öğrenciyi örnekleme dâhil etmeye engel oluşturmuştur ancak bu kategoride tablolar yorumlanırken sayısal olarak iki cinsiyet arasındaki fark dikkate alınarak hareket edilmiştir. Tabloya göre üniversite/sözel bölümde okuyan kız/erkek öğrencilerin İstiklal Marşı'ndaki anahtar kelimeleri bilme düzeyleri arasında herhangi bir farkııı̆ın bulunmadığı görülmektedir. Kız/erkek öğrencilerin tüm anahtar kelimelerdeki başarı düzeyleri birbirine paralel seyretmektedir ancak tablonun bütününde kız öğrencilerin anahtar kelimeleri bilme düzeylerinin erkek öğrencilerin anahtar kelimeleri bilme düzeylerine göre bir miktar daha fazla olduğu söylenebilir. 
Tablo 11.

Istiklal Marşı'ndaki Anahtar Kelimelerin Üniversite/Sayısal Bölüm Öğrencileri Tarafından Bilinme Durumları

\begin{tabular}{lcccc}
\hline Anahtar Kelime & \multicolumn{2}{c}{ Doğru Bilme } & \multicolumn{2}{c}{ Yanlış Bilme } \\
\hline & Kız & Erkek & Kız & Erkek \\
\hline Sancak & 20 & 8 & 7 & 2 \\
Sönmeden & 22 & 9 & 5 & 1 \\
Ocak & 18 & 4 & 9 & 6 \\
Irkıma & 17 & 7 & 10 & 3 \\
Celal & 5 & 2 & 22 & 8 \\
Ezel & 16 & 6 & 11 & 4 \\
Bent & 4 & 1 & 23 & 9 \\
Garp & 7 & 3 & 20 & 7 \\
Afak & 5 & 1 & 22 & 9 \\
Serhat & 19 & 7 & 8 & 3 \\
Hayâsızca & 20 & 6 & 7 & 4 \\
Alçaklara & 21 & 7 & 6 & 3 \\
Incitme & 24 & 9 & 3 & 1 \\
Şüheda & 10 & 8 & 17 & 2 \\
Cüda & 5 & - & 22 & 10 \\
Mabet & 10 & 1 & 17 & 9 \\
Şehadet & 18 & 7 & 9 & 3 \\
Vecd & 3 & - & 24 & 10 \\
Ceriham & 2 & - & 25 & 10 \\
Ruh-ı mücerret & 1 & - & 26 & 10 \\
İzmihlal & 2 & - & 25 & 10 \\
Şafak & 20 & 4 & 7 & 6 \\
\hline & & & &
\end{tabular}

Tablo 11'de üniversite/sayısal bölümlerde okuyan 27'si kız, 10'u erkek olmak üzere toplam 37 öğrencinin İstiklal Marşı'ndaki anahtar kelimeleri doğru/yanlış bilme durumuna ilişkin veriler yer almaktadır. Tabloya göre İstiklal Marşı'nın ilk iki kıtasındaki anahtar kelimeler, kız/erkek öğrenciler tarafından eş düzeyde bilinirken celal kelimesi her iki grup tarafından da en az bilinen kelimedir. İstiklal Marşı'nın üçüncü, dördüncü, beşinci ve altıncı kıtasında yer alan anahtar kelimelerden bent, garp, afak yine her iki grup tarafından en az bilinen kelimelerdir ve bu kelimeleri bilmeme düzeyi her iki grupta da paraleldir. İstiklal Marşı'nın yedinci, sekizinci, dokuzuncu ve onuncu kıtasında yer alan anahtar kelimelerden şafak ve şehadet dışındaki cüda, mabet, vecd, ceriham, ruh-ı mücerret, izmihlal kelimelerinde her iki grupta da dikkat çeken bir başarısızlık söz konusudur. Bilhassa erkek öğrencilerin bahsi geçen anahtar kelimeleri bilme düzeylerinin kız öğrencilerin bu kelimeleri bilme düzeylerinden çok daha düşük olduğu görülmektedir. Yalnız şüheda kelimesinin kız öğrenciler tarafından az bilinmesine karşın erkek öğrencilerin bu kelimeyi bilme konusunda daha başarılı olduğu saptanmıştır. Tablo genelinde üniversite/sayısal bölümdeki erkek öğrencilerin İstiklal Marşı'ndaki anahtar kelimeleri bilme düzeyleri, kız öğrencilerin bu kelimeleri bilme düzeylerine göre oldukça düşük seviyededir. 
İstiklal Marşı'nın Anlaşılma Düzeyinin Tespitine Yönelik Betimsel Bir Çalışma (Lise ve Üniversite Öğrencileri Örneği)

Tablo 12.

Istiklal Marşı'ndaki Anahtar Kelimelerin Üniversite/Eşit Ağırlık Bölüm Öğrencileri Tarafından Bilinme Durumları

\begin{tabular}{lcccc}
\hline Anahtar Kelime & \multicolumn{2}{c}{ Doğru Bilme } & \multicolumn{2}{c}{ Yanlış Bilme } \\
\hline & Kız & Erkek & Kız & Erkek \\
\hline Sancak & 5 & 4 & 2 & 3 \\
Sönmeden & 6 & 5 & 1 & 2 \\
Ocak & 6 & 6 & 1 & 1 \\
Irkıma & 5 & 4 & 2 & 3 \\
Celal & 4 & 3 & 3 & 4 \\
Ezel & 6 & 5 & 1 & 2 \\
Bent & 4 & 2 & 3 & 5 \\
Garp & 2 & 3 & 5 & 4 \\
Afak & 1 & - & 6 & 7 \\
Serhat & 1 & - & 6 & 7 \\
Hayâsızca & 5 & 3 & 2 & 4 \\
Alçaklara & 6 & 5 & 1 & 2 \\
Incitme & 6 & 6 & 1 & 1 \\
Şüheda & 1 & - & 6 & 6 \\
Cüda & - & - & 7 & 7 \\
Mabet & 1 & 2 & 6 & 5 \\
Şehadet & 2 & 2 & 5 & 5 \\
Vecd & - & - & 7 & 7 \\
Ceriham & - & - & 7 & 7 \\
Ruh-ı mücerret & 1 & - & 6 & 7 \\
İzmihlal & - & - & 7 & 7 \\
Şafak & 3 & 2 & 4 & 5 \\
\hline & & & &
\end{tabular}

Tablo 12'de üniversite/eşit ağırlık bölümlerinde okuyan 7'si kız, 7'si erkek olmak üzere toplam 14 öğrencinin i̇stiklal Marşı'ndaki anahtar kelimeleri doğru/yanlış bilme durumu sayısal verilerle listelenmiştir. Tabloya göre kız/erkek öğrencilerin tüm anahtar kelimelerde doğru/yanlış bilme durumları eş düzeydedir. Her iki grubun da en başarısız olduğu kelimeler dördüncü kıtadaki afak, serhat, yedinci kıtadaki şüheda, cüda; sekizinci kıtadaki mabet; dokuzuncu kıtadaki vecd, ceriham, ruhI mücerret ve onuncu kıtadaki izmihlaldir. Nitekim söz konusu kelimelerin kız öğrenciler tarafından bilinme düzeyleri, erkek öğrencilerin bu kelimeleri bilme düzeyinden daha yüksek olduğu görülmektedir; ancak cüda, vecd, ceriham, izmihlal kelimelerini her iki gruptan da bilen olmamıştır.

Tablo 13.

Istiklal Marşı'ndaki Anahtar Kelimelerin Üniversite Öğrencileri Tarafından Bilinme Durumları

\begin{tabular}{|c|c|c|c|c|}
\hline \multirow[t]{2}{*}{ Anahtar Kelime } & \multicolumn{2}{|c|}{ Doğru Bilme } & \multicolumn{2}{|c|}{ Yanlış Bilme } \\
\hline & Kız & Erkek & $\mathrm{KIz}$ & Erkek \\
\hline Sancak & 55 & 27 & 19 & 10 \\
\hline Sönmeden & 63 & 32 & 11 & 5 \\
\hline Ocak & 52 & 26 & 22 & 11 \\
\hline Irkıma & 62 & 29 & 12 & 8 \\
\hline Celal & 39 & 20 & 35 & 17 \\
\hline Ezel & 57 & 28 & 17 & 9 \\
\hline Bent & 33 & 12 & 41 & 25 \\
\hline Garp & 40 & 21 & 34 & 16 \\
\hline Afak & 26 & 12 & 48 & 25 \\
\hline Serhat & 55 & 24 & 19 & 13 \\
\hline
\end{tabular}




\begin{tabular}{lcccc}
\hline Hayâsızca & 58 & 25 & 16 & 12 \\
Alçaklara & 62 & 30 & 12 & 7 \\
İncitme & 66 & 32 & 8 & 5 \\
Şüheda & 31 & 21 & 43 & 16 \\
Cüda & 20 & 7 & 54 & 30 \\
Mabet & 36 & 19 & 38 & 18 \\
Şehadet & 47 & 26 & 27 & 11 \\
Vecd & 13 & 4 & 61 & 33 \\
Ceriham & 10 & 5 & 64 & 32 \\
Ruh-ı mücerret & 12 & 4 & 62 & 33 \\
İzmihlal & 9 & 3 & 65 & 34 \\
Şafak & 63 & 22 & 11 & 15
\end{tabular}

Tablo $13^{\prime}$ te üniversite düzeyinde $74^{\prime}$ ü kız, 37'si erkek olmak üzere toplam 111 öğrencinin İstiklal Marşı'ndaki anahtar kelimeleri doğru/yanlış bilme durumuna ilişkin veriler yer almaktadır. Tabloya göre kız/erkek öğrenciler tarafından en çok bilinen sancak, sönmeden, ocak, ırk, ezel, serhat, hayasızca, alçak, incitme, şafak kelimelerindeki doğru/yanlış bilme durumlarının her iki grupta da eş düzeyde olduğu söylenebilir. Öğrenciler tarafından orta düzeyde bir başarının sağlandığı bent, garp, afak, şehadet kelimelerinin kız/erkek öğrenciler tarafından bilinmeme düzeylerinin paralel olduğunu söylemek mümkündür. Ayrıca kız/erkek öğrenciler açısından doğru/yanlış bilme düzeyleri birbirine paralel olan celal ve şüheda kelimelerinin erkek öğrenciler tarafından kızlara oranla daha fazla bilindiği görülmektedir.

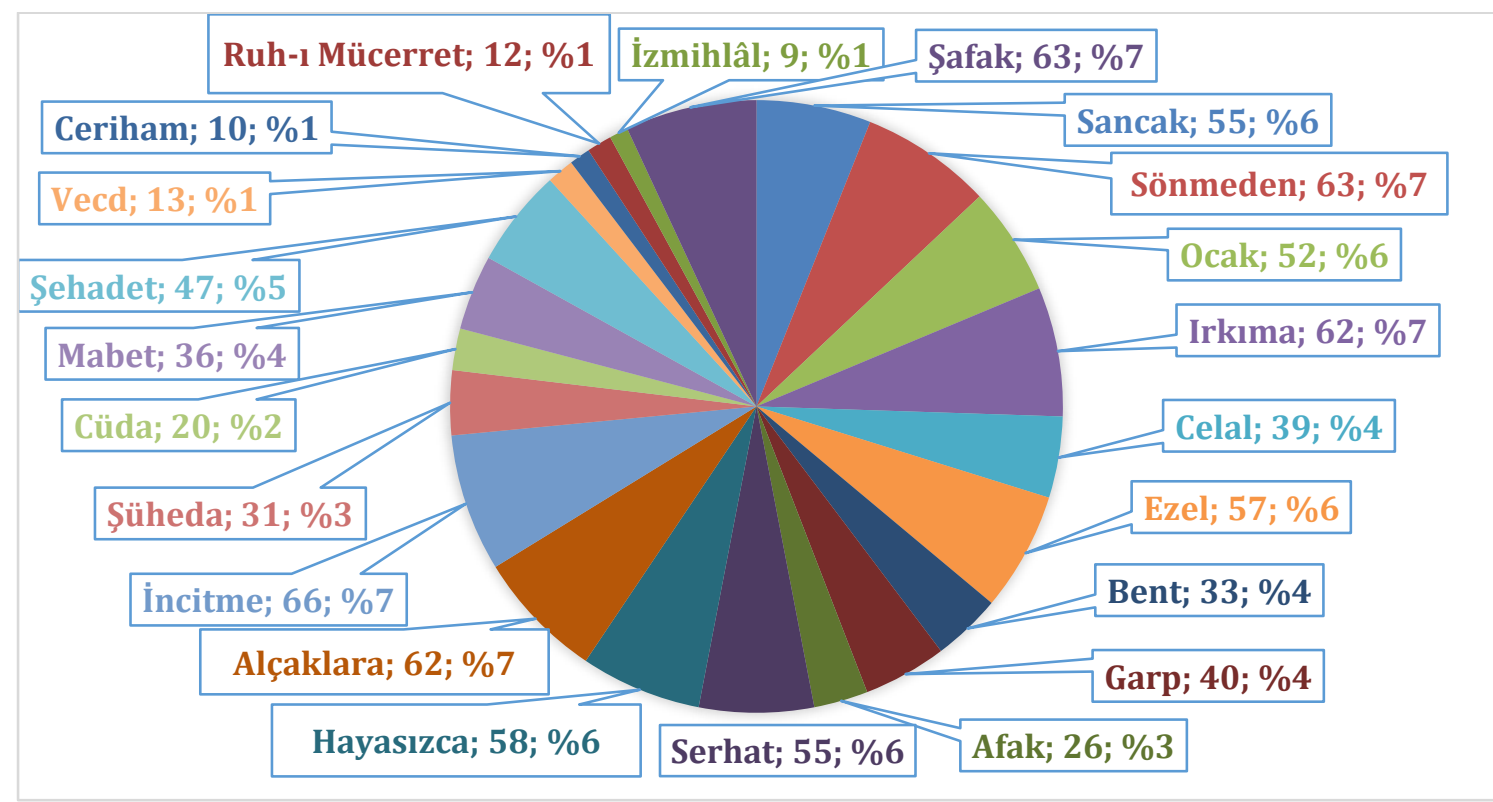

Grafik 5. Üniversite/Kız Öğrenciler Tarafından Doğru Bilinen Anahtar Kelimelerin Oransal Dağılımı

Grafik 5'te üniversite/kız öğrencilerin İstiklal Marşı'ndaki anahtar kelimeleri doğru bilme durumları yüzdelik değerler üzerinden gösterilmiştir. 
İstiklal Marşı'nın Anlaşılma Düzeyinin Tespitine Yönelik Betimsel Bir Çalışma (Lise ve Üniversite Öğrencileri Örneği)

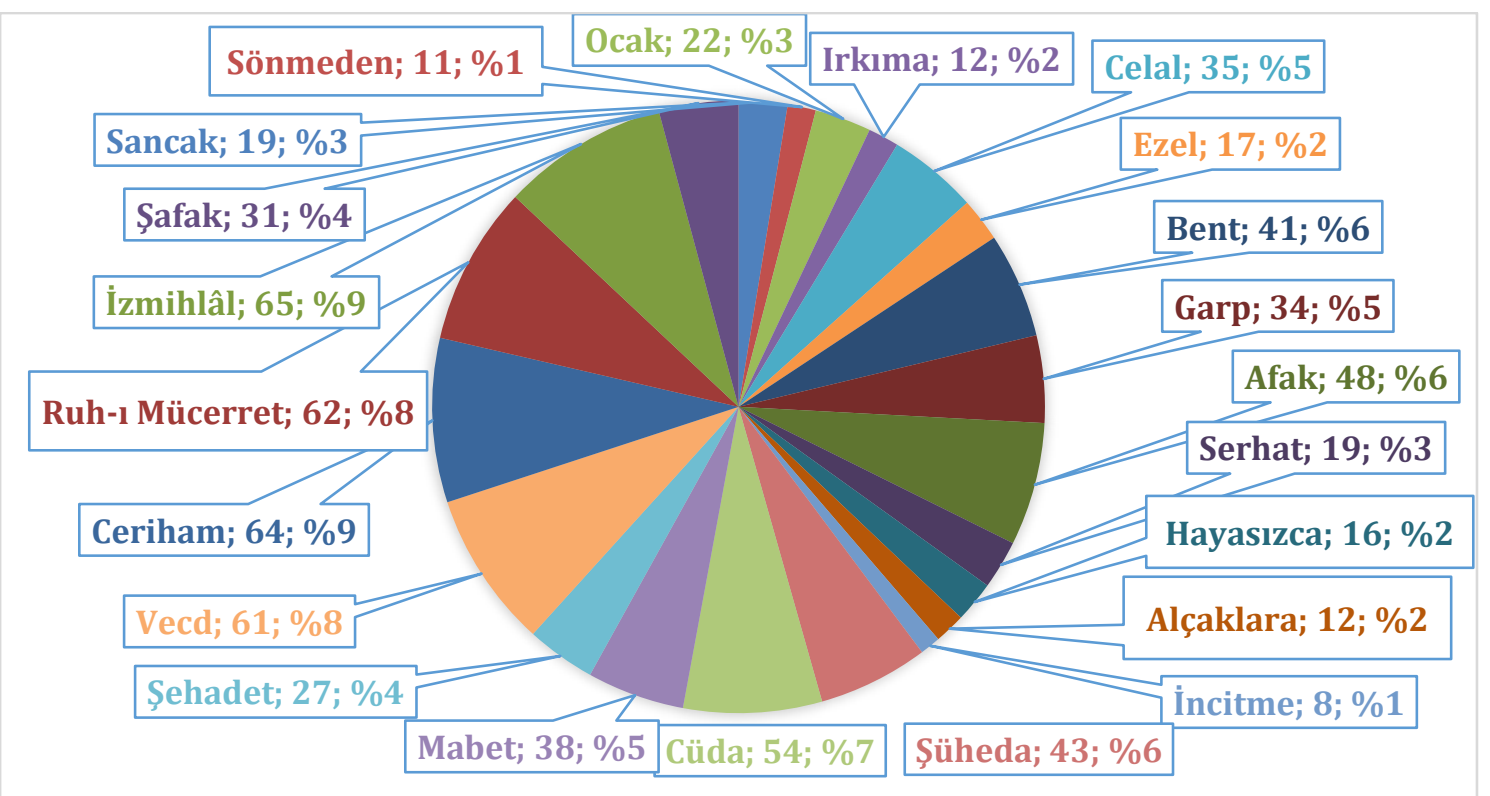

Grafik 6. Üniversite/Kız Öğrenciler Tarafından Yanlış Bilinen Anahtar Kelimelerin Oransal Dağılımı

Grafik 6'da üniversite/kız öğrencilerin İstiklal Marşı́ndaki anahtar kelimeleri yanlış bilme durumları yüzdelik değerler üzerinden gösterilmiştir.

Grafik 5 ve Grafik 6'daki üniversite/kız öğrencilere ait sayısal veriler topluca değerlendirilmiş ve bu verilerden yola çıkılarak tablo 14 oluşturulmuştur:

Tablo 14.

Üniversite/Kız Öğrencilerin İstiklal Marşı'ndaki Anahtar Kelimeleri Doğru/Yanlış Bilme Frekans ve Yüzdelikleri

\begin{tabular}{lclc}
\hline \multicolumn{2}{c}{ Doğru Bilme Frekans ve Yüzdelik } & \multicolumn{2}{c}{ Yanlış Bilme Frekans ve Yüzdelik } \\
\hline Kelime & Frekans/Yüzdelik & Kelime & Frekans/Yüzdelik \\
\hline Incitme & $66, \% 7$ & İzmihlal & $65, \% 9$ \\
Şafak & $63, \% 7$ & Ceriham & $64, \% 9$ \\
Sönmeden & $63, \% 7$ & Ruh-ı Mücerret & $62, \% 8$ \\
Irkıma & $62, \% 7$ & Vecd & $61, \% 8$ \\
Alçaklara & $62, \% 7$ & Cüda & $54, \% 7$ \\
Hayasızca & $58, \% 6$ & Afak & $48, \% 6$ \\
Ezel & $57, \% 6$ & Şüheda & $43, \% 6$ \\
Sancak & $55, \% 6$ & Bent & $41, \% 6$ \\
Serhat & $55, \% 6$ & Mabed & $38, \% 5$ \\
Ocak & $52, \% 6$ & Celal & $35, \% 5$ \\
Şehadet & $47, \% 5$ & Garp & $34, \% 5$ \\
Garp & $40, \% 4$ & Şafak & $31, \% 4$ \\
Celal & $39, \% 4$ & Şehadet & $27, \% 4$ \\
Mabed & $36, \% 4$ & Ocak & $22, \% 3$ \\
Bent & $33, \% 4$ & Serhat & $19, \% 3$ \\
Şüheda & $31, \% 3$ & Sancak & $19, \% 3$ \\
Afak & $26, \% 3$ & Ezel & $17, \% 2$ \\
Cüda & $20, \% 2$ & Hayasızca & $16, \% 2$ \\
Vecd & $13, \% 1$ & Alçaklara & $12, \% 2$ \\
Ruh-ı Mücerret & $12, \% 1$ & Irkıma & $12, \% 2$ \\
Ceriham & $10, \% 1$ & Sönmeden & $11, \% 1$ \\
Izmihlal & $9, \% 1$ & Incitme & $8, \% 1$
\end{tabular}


Tablo 14'te üniversite/kız öğrencilerin İstiklal Marşı'ndaki anahtar kelimeleri doğru/yanlış bilme durumlarına ait sayısal veriler, frekans/yüzdelik değerleri ile birlikte çoktan aza doğru sıralanarak aktarılmıştır. Tablodaki verilere göre üniversite/kız öğrenciler tarafından en çok doğru bilinen anahtar kelimeler incitme, şafak, sönmeden, ırkıma, alçaklara iken en çok yanlış bilinen anahtar kelimeler ise izmihlal, ceriham, ruh-ı mücerret, vecd şeklindedir. Bununla birlikte bu grup tarafından en çok yanlış bilinen kelimeler dışındaki tüm kelimelerde ortalama bir başarının sağlandığını söylemek mümkündür.

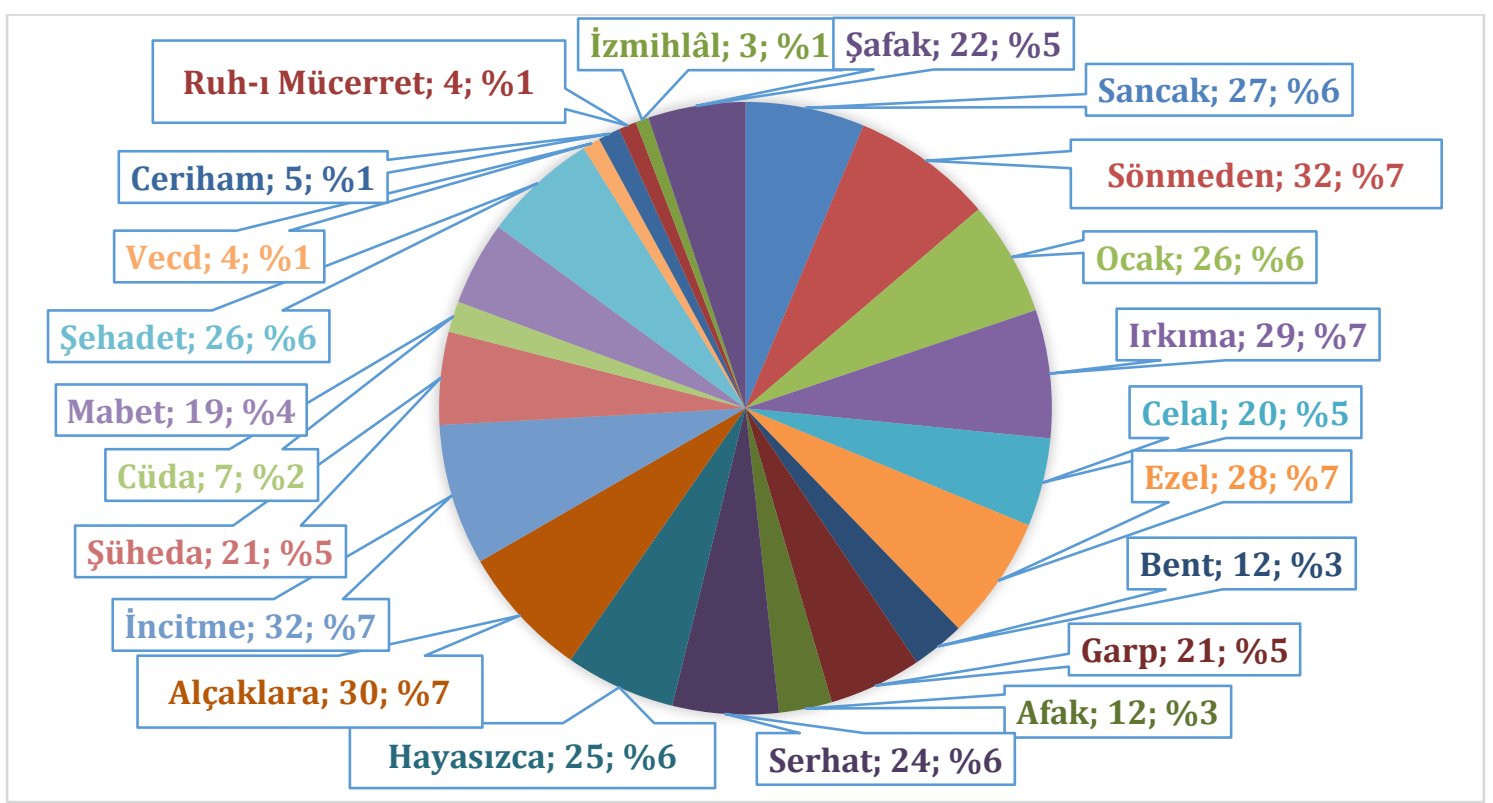

Grafik 7. Üniversite/Erkek Öğrenciler Tarafından Doğru Bilinen Anahtar Kelimelerin Oransal Dağılımı

Grafik 7'de üniversite/erkek öğrencilerin İstiklal Marşı'ndaki anahtar kelimeleri doğru bilme durumları yüzdelik değerler üzerinden gösterilmiştir.

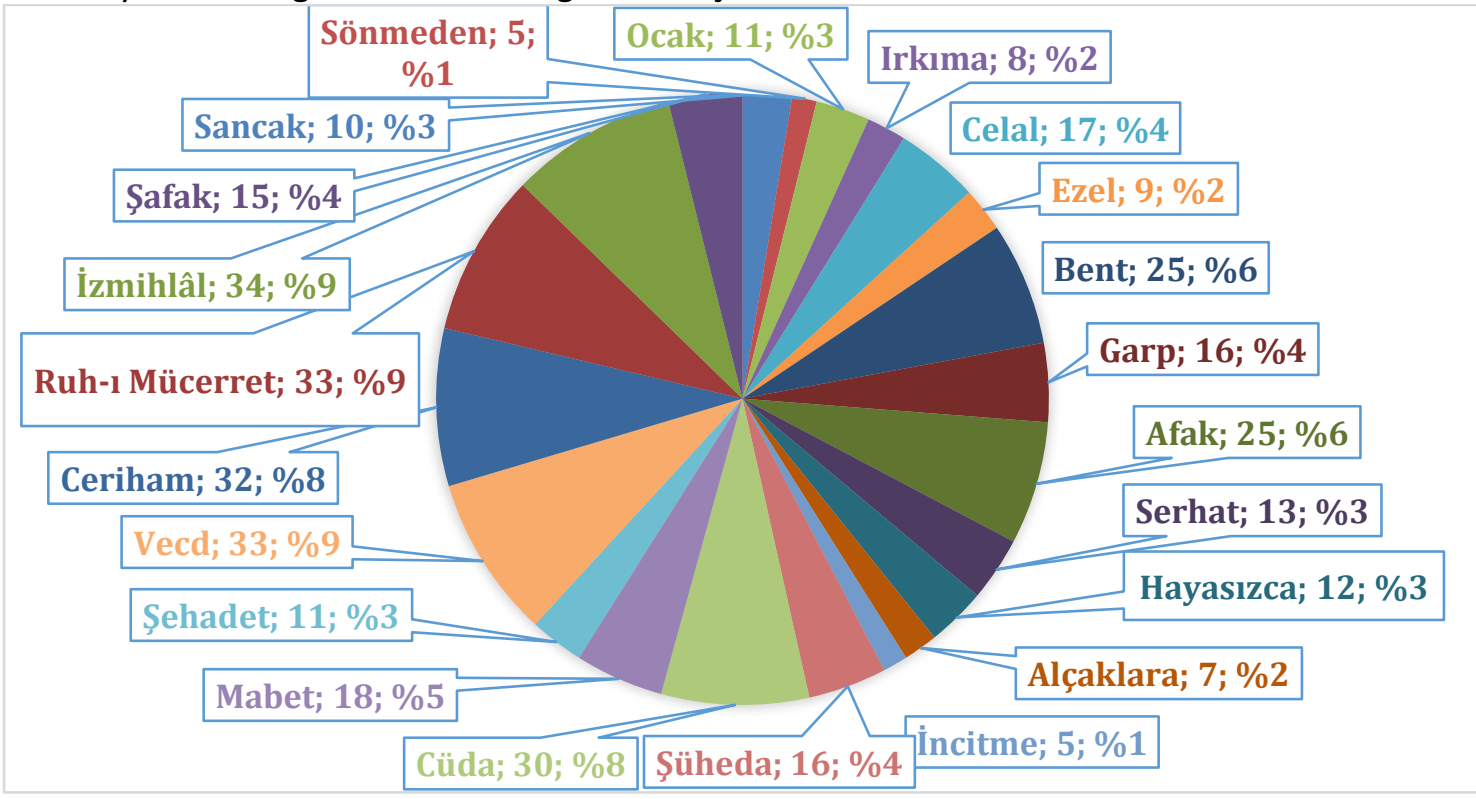

Grafik 8. Üniversite/Erkek Öğrenciler Tarafından Yanlış Bilinen Anahtar Kelimelerin Oransal Dağııımı

Grafik 8'de üniversite/erkek öğrencilerin İstiklal Marşı'ndaki anahtar kelimeleri yanlış bilme durumları yüzdelik değerler üzerinden gösterilmiştir.

Grafik 7 ve Grafik 8'deki üniversite/erkek öğrencilere ait sayısal veriler topluca değerlendirilmiş ve bu verilerden yola çıkılarak tablo 15 oluşturulmuştur: 
İstiklal Marşı'nın Anlaşılma Düzeyinin Tespitine Yönelik Betimsel Bir Çalışma (Lise ve Üniversite Öğrencileri Örneği)

Tablo 15.

Üniversite/Erkek Öğrencilerin Istiklal Marşı'ndaki Anahtar Kelimeleri Doğru/Yanlış Bilme Frekans ve Yüzdelikleri

\begin{tabular}{lclc}
\hline \multicolumn{2}{c}{ Doğru Bilme Frekans ve Yüzdelik } & \multicolumn{2}{c}{ Yanlı̧ Bilme Frekans ve Yüzdelik } \\
\hline Kelime & Frekans/Yüzdelik & Kelime & Frekans/Yüzdelik \\
\hline Sönmeden & $32, \% 7$ & İzmihlal & $34, \% 9$ \\
Incitme & $32, \% 7$ & Ruh-ı Mücerret & $33, \% 9$ \\
Alçaklara & $30, \% 7$ & Vecd & $33, \% 9$ \\
Irkıma & $29, \% 7$ & Ceriham & $32, \% 8$ \\
Ezel & $28, \% 7$ & Cüda & $30, \% 8$ \\
Sancak & $27, \% 6$ & Bent & $25, \% 6$ \\
Ocak & $26, \% 6$ & Afak & $25, \% 6$ \\
Şehadet & $26, \% 6$ & Mabed & $18, \% 5$ \\
Hayasızca & $25, \% 6$ & Celal & $17, \% 4$ \\
Serhat & $24, \% 6$ & Garp & $16, \% 4$ \\
Şafak & $22, \% 5$ & Şüheda & $16, \% 4$ \\
Garp & $21, \% 5$ & Şafak & $15, \% 4$ \\
Şüheda & $21, \% 5$ & Serhat & $13, \% 3$ \\
Celal & $20, \% 5$ & Hayasızca & $12, \% 3$ \\
Mabed & $19, \% 4$ & Ocak & $11, \% 3$ \\
Bent & $12, \% 3$ & Şehadet & $11, \% 3$ \\
Afak & $12, \% 3$ & Sancak & $10, \% 3$ \\
Cüda & $7, \% 2$ & Ezel & $9, \% 2$ \\
Ceriham & $5, \% 1$ & Irkıma & $8, \% 2$ \\
Vecd & $4, \% 1$ & Alçaklara & $7, \% 2$ \\
Ruh-ı Mücerret & $4, \% 1$ & Sönmeden & $5, \% 1$ \\
Izmihlal & $3, \% 1$ & İncitme & $5, \% 1$ \\
& & & \\
\hline & & &
\end{tabular}

Tablo 15'te üniversite/erkek öğrencilerin İstiklal Marşı'ndaki anahtar kelimeleri doğru/yanlış bilme durumlarına ait sayısal veriler, frekans/yüzdelik değerleri ile birlikte çoktan aza doğru sıralanarak aktarılmıştır. Tablodaki verilere göre üniversite/erkek öğrenciler tarafından en çok doğru bilinen anahtar kelimeler sönmeden, incitme, alçaklara, ırkıma, ezel iken en çok yanlış bilinen anahtar kelimeler ise izmihlal, ruh-ı mücerret, vecd, ceriham, cüda şeklindedir. Üniversite/kız grubunda olduğu gibi üniversite/erkek grubunda da en çok yanlış bilinen kelimeler dışındaki tüm kelimelerde orta düzeyde bir başarının sağlandığı söylenebilir.

\section{Tartışma ve Sonuç}

Bu çalışma kapsamında lise son sınıf öğrencileri ile üniversite son sınıf öğrencilerinin İstiklal Marşı'ndaki anahtar kelimeleri doğru/yanlış bilme durumları belirlenmiş ve ulaşılan verilerin cinsiyet veya sözel/sayısal/eşit ağırlık gibi değişkenler açısından farklılık içerip içermediği irdelenmiştir.

Çalışma sonucunda i̇stiklal Marşı'nın tüm kıtalarından belirlenen anahtar kelimelerin öğrenciler tarafından bilinme düzeylerinin değişkenlik gösterdiği sonucuna ulaşılmıştır. Arslan'ın (2013) üniversite öğrencilerine uyguladığı benzer çalışmasında da İstiklal Marşı'ndaki anahtar kelimelerin bilinme oranlarının bazı kelimelerde yüksek, bazı kelimelerde ise düşük düzeyde olduğu -örneğin sancak kelimesinin bilinme oranı \%79 iken, bend kelimesinin bilinme oranı \%3,3'tür- belirlenmiştir. Bu çalışma neticesinde marşın bütün anahtar kelimelerine ilişkin değerlerin topluca değerlendirilmesiyle kelimelerin \%33,8'inin bilindiği, \%66,1'inin ise bilinmediği tespit edilmiştir. İşcan ve şimşek (2012), üniversite öğrencilerinin İstiklal Marşı algısını inceledikleri çalışmalarında, öğrencilerin İstiklal Marşı'nın öneminin farkında oldukları, ancak anlamının öğrenciler tarafından tam olarak kavranamadığı, neticede okullarda marşın gerektiği şekilde öğretilemediği, öğretiminde ezberden öteye geçilemediği, özellikle marşın anlam dünyası üzerinde durulmadığı gibi düşünceler taşıdıkları sonuçlarına 
ulaşmışlardır. Oysaki İstiklal Marşı öğretilirken marştaki her kelimenin anlamı üzerinde titizlikle durulmalı; marş, bütüncül bir bakış açısıyla ve hatta metinler arası okuma eylemleriyle de tarihî, millî değerlerle birleştirilerek değerlendirilmelidir. Nitekim Alev'e (2014: 15-17) göre yazııdığı dönemin sosyal, siyasal ve psikolojik şartlarını ince ince kodlayan İstiklal Marşı, eğitimin her kademesinde değerler eğitimi açısından ne derece önemli ise metinler arası okuma özelliği bakımından da o derece önemlidir. Mehmet Akif'in, Ben ezelden beridir hür yaşadım, hür yaşarım / Kükremiş sel gibiyim bendimi çiğner aşarım/ Bu ezanlar ki şehadetleri dinin temeli / Ebedi yurdumun üstünde benim inlemeli örneklerinde görüldüğü gibi her mısradaki ben ifadeleri Akif'in kendi beni değil, milletin ruhunun beni olması durumu, Kuran'ın bazı ayetlerinde Allah'ın azameti anlatılırken de biz ifadesinin kullanılması ile paralellik göstermektedir. Yine XIII. yüzyılda Anadolu Selçuklu Devleti'nin Moğol istilası sonucu çöküşe geçtiği bir dönemde yaşamış olan Yunus Emre'nin hayattan ümidini kesen topluma umut vermek için yazdığı ...ölümden ne korkarsın, korkma ebedi varsın dizesi ile İstiklal Marşı'ndaki Korkma, sönmez bu şafaklarda yüzen al sancak dizesi aynı gaye ve heyecanla yazılmıştır.

İstiklal Marşı ile ilgili yukarıda izah edilen durumlar, İşcan ve Şimşek'in (2012) çalışmalarında ulaştıkları sonuçlardan biri olan marşın toplum tarafından sadece törenlerde okunan sıradan bir şiir gibi algılandığı, bunun önüne geçebilmek için de marşın okullarda ayrı bir ders olarak okutulması gerekliliği durumları ile örtüşür niteliktedir. Marşla ilgili yapılan pek çok çalışmada, öğrencilerin çoğunun marşın tamamını ezbere bilmedikleri, marşta geçen kimi kelimelerin anlamlarını dahi bilmemeleri tespitlerinin milletin geleceği için vahim sonuçlar doğuracağı belirtilmektedir.

Bu çalışmanın bulguları lise düzeyindeki erkek öğrencilerin kelimeleri bilme düzeylerinin sözel/sayısal/eşit ağırlık değişkenlerine bağlı olmaksızın -özellikle kimi kelimelerde- kız öğrencilerin kelimeleri bilme düzeylerinden biraz daha yüksek olduğunu göstermektedir. Örneğin hemen her bölümdeki lise/kız öğrencilerin celal (11 kız) ve şüheda $(13 \mathrm{kIz})$ kelimelerini bilme düzeylerinin erkek öğrencilerin (celal: 20 erkek, şüheda: 22 erkek) bu kelimeleri bilme düzeylerinden daha düşük olduğu saptanırken ocak, garp, ırk kelimelerini ise kız öğrencilerin (ocak: 36 kız, garp: 19 kız, ırk:42 kız) bilme düzeyleri erkek öğrencilerin (ocak: 24 erkek, garp: 12 erkek, ırk: 34 erkek) bu kelimeleri bilme düzeylerine göre daha yüksek olduğu belirlenmiştir. Bu durumun kelimelerin kavram alanları ile bireylerin cinsiyetleri arasındaki ilişkiye bağlı olarak geliştiği düşünülebilir. Bütüncül bir bakış açısıyla değerlendirildiğinde lise sözel/kız-erkek öğrencilerin kelimeleri bilme konusunda diğer bölümlerdeki öğrencilerden daha başarılı olduklarını söylemek mümkündür. Marştaki anahtar kelimeleri bilme konusunda en başarısız bölüm ise sayısal bölüm olarak görülmektedir. Bu ayrıntılar hariç kız/erkek öğrenciler tarafından bölüm değişkenine bağlı olmadan genel anlamda en çok bilinen kelimeler; sancak (59), sönmeden (74), ocak (60), ırk (76) iken en az bilinen kelimeler ise afak (17), cüda (13), vecd (16), ceriham (11), ruh-ı mücerret (9) ve izmihlal (7) olarak belirlenmiştir.

Lise düzeyinde her iki cinsiyetten ve bölüm değişkenlerinden eşit sayıda öğrenci evrenden örnekleme dâhil edilirken üniversite düzeyindeki neredeyse tüm bölümlerde kız öğrencilerin erkek öğrencilerden sayıca fazla olması ve üniversitenin ağılıklı olarak sözel temelli bölümlerden oluşması eşit sayıda kız/erkek, sözel/sayısal/eşit ağırık değişkenli öğrenciyi örnekleme dâhil etmeye engel teşkil etmiştir. Ancak bu grupta tablolar yorumlanırken sayısal olarak bu farklar, dikkate alınarak çıkarımlarda bulunulmuştur. Bu kategorideki çalışma sonuçları, üniversite/sözel bölüm öğrencilerinin marştaki anahtar kelimeleri bilme konusunda oldukça başarılı olduğunu göstermektedir. (Hatta kız öğrencilerin erkek öğrencilere göre bir derece daha başarılı olduklarını söylemek mümkündür.) Bu durumun üniversitenin sözel bölümlerinden özellikle Türk Dili ve Edebiyatı, Türkçe Öğretmenliği, Tarih Bölümü gibi branşlarda okutulan Eski Türk Edebiyatı, Osmanlı Türkçesi ve türevleri derslerde yabancı kelimelerin yoğun olduğu metinlerin irdelenmesi ile ilgili olabileceği yorumu yapılabilir. Üniversite grubundaki en başarısız bölüm ise sayısal temelli bölümlerdir. Üniversite sayısal/eşit ağırlık/erkek öğrencilerin bilhassa vecd, ceriham, ruh-ı mücerret ve izmihlal kelimelerini yüzde yüz bilmeme durumları, dikkate değer bir sonuçtur. Üniversite kategorisindeki veriler bütüncül bir bakış açısıyla değerlendirildiğinde kız/erkek öğrencilerin bölüm değişkenlerine bağlı olmaksızın bend (45), garp (61), afak (38), şehadet (73) kelimelerinde orta düzeye yakın başarı sağladıkları; sancak (82), sönmeden (95), ocak (78), ırk (91), ezel (85), serhat (79), hayasızca (83), alçak (92), incitme (98), şafak (85) kelimelerinin ise en çok bilinen kelimeler olduğu söylenebilir. 

Örneği)

Neticede çalışmada tespit edilen bulgulardan hareketle ülkemizde eğitimin her kademesinde İstiklal Marşı'nın tarihî, sosyal, kültürel ve millî değerler açısından özümsenebilmesi için ilk iki kıta/sonraki kıtalar ayrımı yapılmaksızın marşın bütüncül bir bakış açısıyla okutulması ve her mısrasındaki tüm kelimelerinin üzerinde titizlikle durulması gerekmektedir. Bu noktada Millî Eğitim Bakanlığı ve üniversitelerin özellikle eğitim fakültelerine büyük sorumluluk düşmektedir. Ayrıca Mehmet Akif Ersoy'un gerek şahsiyeti (Mehmet Akif Ersoy'un şahsiyeti; vatanını, milletini, bayrağını seven nesiller yetiştirme noktasında örnek bir rol modeldir.) gerekse eserleri ve özellikle İstiklal Marşı ile ilgili alanda yapılmış çok kıymetli çalışmalar (Alev, 2014; Çetin, 2014; Tay ve Nalçacı, 2020;) bulunmaktadır. Dolayısıyla aktif eğitimin her kademesinde bu çalışmalardan faydalanmak, marşın ritmine uygun ya da ezbere muntazam okunması yanında derin mana sisteminin de anlaşılması açısından önem arz etmektedir. Zira Türk tarih/edebiyatına, evrensel değerleri yerli unsurlarla bezeyerek iz bırakmış olan Mehmet Akif'in eserlerini anlamak, mensubu olduğu toplumun ruhunu anlamak demektir.

\section{Araştırma ve Yayın Etiği}

Bu çalışmada "Yükseköğretim Kurumları Bilimsel Araştırma ve Yayın Etiği Yönergesi" kapsamında uyulması belirtilen tüm kurallara uyulmuştur. Yönergenin ikinci bölümü olan "Bilimsel Araştırma ve Yayın Etiğine Aykırı Eylemler" başlığı altında belirtilen eylemlerden hiçbiri gerçekleştirilmemiştir.

\section{Yazarların Katkı Oranı}

Çalışma tek yazarlı olup bütün araştırma sorumlu yazara aittir.

\section{Çıkar Çatışması}

Bu çalışmada çıkar çatışması teşkil edebilecek herhangi bir durum ve ilişki yoktur.

\section{Kaynaklar}

Acar, K. (2018). İstiklal Marşı'nın söz varlığı üzerinde analitik bir inceleme denemesi." TÜRÜK Uluslararası Dil, Edebiyat ve Halkbilimi Araştırmaları Dergisi, 6(13), 370-381.

Aktaş, Ş. (1989). Mehmet Akif ve insan. Hece (Mehmet Akif Özel Sayısı), 133, 25-37.

Alev, K. (2014). İstiklal Marşı'nın kültürel kodları ve metinler arası ilişkiler. FSM ilımi Araştırmalar Insan ve Toplum Bilimleri Dergisi, 3, 11-25.

Arslan, A. (2013). Üniversite öğrencilerinin İstiklal Marşı́ndaki anahtar kelimeleri bilme durumları. Turkish Studies, 8(1), 735-746.

Atalay Mazlum, A. ve Mazlum, M. M. (2017). Sosyal bilimlerde araştırma yönteminin belirlenmesi. Route Educational and Social Science Journal, 4(4), 1-21.

Atasoy, F.O. (2010). İstiklal Marşı'nın noktalaması. International Periodical for the Languager, Literature and History of Turkish or Turkic, 5(3), 763-789.

Aydoğan, B. (1997). Mehmet Akif Ersoy'un meyhane ve mahalle kahvesi şiirleri üzerine bir değerlendirme. Türkoloji Araştırmaları, 85-106.

Ayvazoğlu, B. (1986). İstiklal Marşı tarihi ve anlamı. İstanbul: Tercüman Yayınları.

Baş, S. (2012). Bir merhamet şairi olarak Mehmet Akif. Turkish Studies, 7(2), 193-217.

Boşnakoğlu, H. (1981). Istiklal Marşı şairimizin istiklal harbindeki vaazları. İstanbul: Er-Tu Matbaası.

Büyüköztürk, Ş.; Kılıç Çakmak, E.; Akgün, Ö. E.; Karadeniz, Ş.; Demirel, F. (2016). Bilimsel araştırma yöntemleri. Ankara: Pegem Akademi.

Canım, R. ve Çalık, E. (2007). Mehmet Akif Ersoy ve İstiklal Marşı. İstanbul: Nüve Kültür Merkezi.

Çapku, A. (2017). Mehmet Akif Ersoy'un şiirlerinde ilahi adalet ve kötülük meselesi. RumeliDe Dil ve Edebiyat Araştırmaları Dergisi, 8, 43-49.

Çetin, N. (2010). İstiklal Marşımızın tarihî, edebî, dinî ve kültürel kaynakları. Bilim ve Aklın Aydınlığında Eğitim, 121, 6-32.

Çetin, N. (2013). Emperyalizme direnen Türk: Mehmet Akif Ersoy, Ankara: Akçağ Yayınları. 
Çetin, N. (2014). İstiklal Marşı'mızı anlamak. Ankara Üniversitesi Dil ve Tarih-Coğrafya Fakültesi Türkoloji Dergisi, 21(2), 25-92.

Çetişli, i. (2004). Metin tahlillerine giriş I. Ankara: Akçağ Yayınları.

Demirli, E.(2011). Mehmet Akif'in şiirlerinde tasavvuf: Safahat'ı bir tasavvuf-ahlak metni olarak okumak (Ed. Vahdettin Işık), Uluslararası Mehmet Akif Ersoy Sempozyumu Bildiriler Kitabı (s.135-153), İstanbul: Zeytinburnu Belediyesi Kültür Yayınları.

Durmuş, S. (2013). Istiklal Marşı ve Akif'i yeniden anlamak. İstanbul: Alioğlu.

Ercilasun, B. (1987). Mehmet Akif'in şiirlerinde kadın ve aile temi. Hacettepe Üniversitesi Edebiyat Fakültesi Dergisi, 5(1), 34-40.

Ergin, M. (1986). Atatürk ve Akif. Milli Kültür Dergisi, 55, 2-5.

Erol, K. (2014). Mehmet Akif'in şiirlerinde iki anahtar kelime: "cehalet" ve "kavmiyet". Journal of International Social Research, 7(32), 95-110.

Fergan, E.E. (1938). Mehmet Akif hayatı-eserleri. İstanbul: Abdullah Işıklar Kitabevi.

Gökyay, O.S. (1986). Mehmet Akif Ersoy'un dili üzerine. Milli Kültür Dergisi, 55, 10-17.

Gündoğdu, B. (2009). Azerbaycan'da Mehmet Akif hayranı bir şair: Bahtiyar Vahabzade (Ed. G. Yıldız vd.) I. Uluslararası Mehmet Akif Ersoy Sempozyumu (ss. 127-129). Burdur: Mehmet Akif Ersoy Üniversitesi.

Gündüzalp, S. (2008). Mehmet Akif Ersoy hayatı ve eserlerinden seçmeler. İstanbul: Zafer Yayınları.

İmamoğlu, A. (2010). Mehmet Akif'te medeniyet kavramı. Journal of Islamic Research, 21(3), 165-171.

İşcan, A. ve Şimşek, Y. (2012). Üniversite öğrencilerinin İstiklal Marşı algısı. Uluslararası Sosyal Araştırmalar Dergisi, 5(20), 348-360.

Kaplan, M. (2010). Kültür ve dil. İstanbul: Dergâh Yayınları.

Karabulut, M. (2014, Mart). Kültür hayatımızda Mehmet Akif Ersoy ve istiklal Marşı konulu konferans metni, Adıyaman: Adıyaman Üniversitesi. http://turkoloji.cu.edu.tr, Erişim Tarihi: 01.03.2021.

Karagöz, B. ve Şimşek, Y. (2017). Türkçe öğretmeni adaylarının Mehmet Akif Ersoy’a ilişkin görüşleri. Ekev Akademi Dergisi, 21(72), 13-30.

Karataş, E. (2009). Mehmet Akif Ersoy'un kadın konusuna yönelik çevirileri ve Safahat'ta kadın olgusu. (Ed. G. Yıldız vd.) I. Uluslararası Mehmet Akif Ersoy Sempozyumu (ss. 247-257). Burdur: Mehmet Akif Ersoy Üniversitesi.

Kaymaz, R. (2009). Mehmet Akif Ersoy ve Istiklal Marşı. Ankara: Akçağ Yayınları.

Kılıç, A.F. (2008). Milli yürek Mehmet Akif Ersoy'un din ve toplum anlayışı. İstanbul: Değişim.

Kır, i. (1988). Mehmet Akif Ersoy'un görüşlerinin sosyolojik analizi (Yayımlanmamış Yüksek Lisans Tezi). Fırat Üniversitesi, Sosyal Bilimler Enstitüsü, Elazığ.

Kocakaplan, i. (2015). İstiklal Marşımız ve Mehmet Akif Ersoy. İstanbul: Türk Edebiyat Vakfı.

Koçak, M (2016). Mehmet Akif Ersoy, Necip Fazıl Kısakürek ve Sezai Karakoç şiirlerinde bir medeniyet öncüsü olarak Hz. Muhammed. FSM ilmi Araştırmalar Insan ve Toplum Bilimleri Dergisi, 8, 203222. DOI: 10.16947 Ifsmiq, 281699.

Kurnaz, C. (1986). Akif'in şiirlerinde halka hitap etme düşüncesinden kaynaklanan özellikler. Milli Kültür Dergisi, 55.

Okay, O. (2008). Mehmet Akif'in karakteri ve sanatı. Hece (Mehmet Akif Özel Sayısı), 133, 8-24.

Özgen, M. (2013). Mehmet Akif Ersoy'un Türk eğitimine katkıları. Mehmet Akif Ersoy Üniversitesi Eğitim Fakültesi Dergisi, 13(27), 1-22.

Sağer, T. (2010). İstiklal Marşı ve besteleri. Adıyaman Üniversitesi Sosyal Bilimler Enstitüsü Dergisi, 3(5), 214-226.

Sarı, M. (2003). Mehmet Akif Ersoy'un bir şiirinde karamsarlık ve ümit. Afyon Kocatepe Üniversitesi Sosyal Bilimler Dergisi, 5(2-3), 167-191.

Şimşek, T. (2015). Mehmet Akif'in poetikası. Atatürk Üniversitesi Türkiyat Araştırmaları Enstitüsü Dergisi, 55, 105-120.

Tay, B. ve Nalçacı, A. (2020). İstiklal Marşı'mızda değerler. Değerler Eğitimi Dergisi, 18(40), 243-275.

Tekşan, K. ve Çelik, G. (2014). Mehmet Akif Ersoy'un şiirlerinin Türkçe öğretiminde kullanımı. Ana Dili Eğitimi Dergisi, 3(1), 30-46. 

Örneği)

Temizkan, M. (2010). Türkçe öğretiminde yaratıcı yazma becerilerinin geliştirilmesi. Türklük Bilimi Araştırmaları, XXVII, 621-643.

Temizyürek, F. ve Kansızoğlu, H. B. (2016). Mehmet Akif'in Safahat adlı eserinde yer alan şiirlerin çocuk edebiyatı ölçütlerine göre hikâyeleştirilmesi. Çocuk ve Medeniyet, 1, 151-171.

Timurtaş, F.K. (2002). İstiklal Marşı ve Mehmet Akif Ersoy. Belgelerle Türk Tarihi Dergisi, 62, 16-21.

TDK. (2005). Türkçe sözlük. Ankara: TDK Yayınları.

Uç, H. (2009). Mehmet Akif'in hayatı ve eserlerindeki ruhi değişmelerin psikanalitik yorumu. (Ed. G. Yıldız vd.) I. Uluslararası Mehmet Akif Ersoy Sempozyumu, (ss. 355-383). Burdur: Mehmet Akif Ersoy Üniversitesi.

Yaşar, Y. (2018). Türkiye'de millî marşın kabulünde güfte ve beste tartışmaları (Yayımlanmamış yüksek lisans tezi). Ankara Üniversitesi, Sosyal Bilimler Enstitüsü, Ankara.

Zavotçu, G. (2017). İstiklal Marşı'nın temel kavramları. Uluslararası Türkçe Edebiyat Kültür Eğitim Dergisi, 6(4), 2414-2435.

\section{Introduction}

\section{Extended Abstract}

The Turkish National Anthem is a literary poem written in the days when the Turkish nation was tested with pain and poverty in the paw of the West, and struggled for every inch of the land of the country sacrificing their own lives, despite heavy defeats in many wars. Indeed, this anthem was born as "the poetic language of self-confidence, national excitement, enthusiasm and faith that our army and our nation need the most in the hardest days of the national struggle " as emphasized by Çetişli (2004: 156).

When the literature is examined, it is seen that many studies have been conducted in which Mehmet Akif Ersoy has been examined in all aspects. However, it is necessary to focus more on current studies that examine both the person and the works of Akif that he has presented to the service of the society in terms of values education at all levels of the curriculum. Considering that the aim of the Turkish education policy is to raise individuals who are useful to themselves, to their country and to their nation, it is clear that more studies should be conducted on both the person and the works of Mehmet Akif Ersoy.

\section{Method}

This study is a descriptive research designed in accordance with the scanning model. The scanning model, which is a method frequently used in studies especially in the field of social sciences, is the description of a situation existed in the past or today in terms of certain variables. The method is based on data that examine the relationships of questions directed to individuals within the sample representing the universe, in terms of certain characteristics such as gender, age or socio-economic condition (Atalay Mazlum \& Mazlum, 2017: 5-6).

The city center of Kilis was taken as the general universe of the study. The state high schools in Kilis and Kilis 7 Aralık University, were selected as the research population. The sample in the research universe consisted of a total of 222 students, of whom 111 students were in the final year of the state high schools, and 111 students were in the final year in different departments of Kilis 7 Aralık University.

Within the scope of this research, the state of knowing or not knowing the key words in the National Anthem among the senior high school students and the senior university students was determined and it was examined whether the obtained data contained differences in terms of variables including gender and department (the field of study: verbal, quantitative, and Turkish-Math).

\section{Result and Discussion}

The results of the study indicated that among the final year high school students, the level of knowing certain words were slightly higher (\%15) in the males than the females, regardless of the department variable (verbal, quantitative, and Turkish-Math). For example, it was determined that in almost every department in high school, the level of knowing was lower in the female students than 
the male students of the words celal [rage] ( $f=11$ in females, $f=20$ in males) and şüheda [martyrs] ( $f=13$ females, $f=22$ males), on the other hand the female students were more successful in knowing the words ocak [home] ( $f=36$ females, $f=24$ males), garp [west] ( $f=19$ females, $f=12$ males) and Irk [race] ( $f=42$ females, $f=34$ males). It can be considered that this situation occurred depending on the relationship between the conceptual areas of the words and the gender of the individuals. When evaluated from a holistic perspective, it can be possible to say that high school verbal students either female or male were more successful than the students in other departments. The least successful ones were found to be the quantitative students. When gender and the department variables were disregarded, in general, sancak [starboard] $(f=59)$, sönmeden [without blowing out] ( $f=74)$, ocak [home] $(f=60)$ and ırk [race] $(f=76)$ were the most known words, while afak [horizon] $(f=17)$, cüda [remote] $(f=13)$, vecd [rapture] $(f=16)$, ceriham [my wound] $(f=11)$, ruh-ı mücerret [abstract soul] $(f=9)$ and izmihlal [destruction] $(f=7)$ were the least known words.

Equal numbers of students from both genders and departmental variables were included in the sample from the population at the high school level. However, the facts that female students $(f=74)$ outnumber the male students $(f=37)$ in almost all departments at the university level and that the university consists mainly of verbal departments, became an obstacle to include equal numbers of students in terms of gender and department (verbal, quantitative and Turkish-Math) in the sample. However, while interpreting the results in this category, inferences were made by taking into consideration these numerical differences. The research results in this category showed that the university students in verbal departments were quite successful in knowing the key words in the anthem. In addition, the female students were one degree more (\%20) successful than the male students. It could be stated that this condition could be related to the fact that the examination of the texts in which foreign words are intensely present in some lectures such as Old Turkish Literature, Ottoman Turkish and their derivatives taught in the verbal departments of the university, especially in Turkish Language and Literature, Turkish Language Teaching and History departments. The least successful students in the university group were those attending the quantitative departments. It is noteworthy that $100 \%$ of university male students in quantitative and Turkish-Math departments did not know the meaning of certain words such as vecd [rapture], ceriham [my wound], ruh-ı mücerret [abstract soul] and izmihlal [destruction]. When the results in the university category were evaluated from a holistic point of view, it was observed that disregarding the variables of students' gender and department, the students achieved a moderate level of success in knowing the words of bend [connection] ( $f=45)$, garp [west] $(f=61)$, afak [horizon] $(f=38)$, şehadet [martyrdom/shahada] $(f=73)$, whereas, the most known words among the participants were sancak [starboard] $(f=82)$, sönmeden [without blowing out] $(f=95)$, ocak [home] $(f=78)$, Irk [race] $(f=91)$, ezel [pre-eternity] $(f=85)$, serhat [border] $(f=79)$, hayasızca [immodestly] $(f=83)$, alçak [villainous] $(f=92)$, incitme [do not hurt] $(f=98)$, şafak [dawn] (f=85).

As a conclusion, based on the inferences drawn from the present study, In order for the Turkish National Anthem to be internalized in terms of historical, social, cultural and national values at all levels of education in our country, the first two stanzas or the subsequent stanzas without any distinction should be taught from a holistic perspective, and all the words in each line of the poem should be meticulously elaborated. At this point, a great responsibility falls on the Ministry of National Education and especially education faculties of universities. In addition, very valuable studies are available in the field related to both Mehmet Akif Ersoy's personality (his personality is an exemplary role model in raising generations who love their homeland, nation and flag) and his works, especially the National Anthem (Alev, 2014; Çetin, 2014; Tay \& Nalçacı, 2020). Therefore, at every stage of active education, benefiting from these studies will be important reinforcers in terms of the understanding of its deep meaning system as well as proper recitation of the anthem by heart. Because, understanding and absorbing the works of Mehmet Akif, who embraced universal values blending with national principles and left important traces in Turkish history and literature, with a variety of topics and high moral values, also means understanding and internalizing the spirituality and the soul of the Turkish Nation. 